$14^{\text {th }}$ Conf. Agric. Develop. Res., Fac. of Agric., Ain Shams Univ.,

March, 2019, Cairo, Egypt

Special Issue, 27(1), 615 - 633, 2019

Website: http://strategy-plan.asu.edu.eg/AUJASCI/

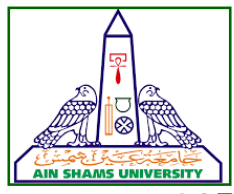

\title{
INFLUENCE OF PRE-HARVEST SALICYLIC AND SOME AMINO ACIDS TREATMENTS ON QUALITY ATTRIBUTES OF PEAR FRUITS CV. LE-CONTE DURING COLD STORAGE AND SHELF LIFE
}

\author{
Khedr E.H. \\ Pomology Dept., Fac. of Agric., Cairo Univ., Giza, Egypt
}

Received 26 March, 2018

Accepted 1 August, 2018

ABSTRACT

This study aimed to determine the relationship between preharvest treatments by salicylic acid, Larginine and L-tryptophan with fruit quality of pear cv. Le-Conte during cold storage at $0^{\circ} \mathrm{C}$ and 90 $95 \% \mathrm{RH}$ for 12 weeks followed by shelf life at $22^{\circ} \mathrm{C}$ for 12 days. Treatments included $L$-arginine at 100 and 200 ppm, L-tryptophan at 50 and 100 ppm, salicylic acid at 100 and 200 ppm and water as control, all treatments were sprayed on mature trees until run off twice; at full bloom stage and at initial fruit set stage. All conducted treatments were effective in maintaining fruit quality compared with control. Tryptophan at $100 \mathrm{ppm}$ showed the highest significant TSS values, while salicylic acid at 200 ppm showed the lowest significant TSS values during cold storage and shelf life circumstances. Salicylic acid at 100 and 200 ppm showed the lowest weight loss percentages, salicylic at $200 \mathrm{ppm}$ decreased the rate of decay incidence, showed the lowest significant respiration rates, also it was effective in alleviating core browning. In addition, salicylic acid at 200 ppm significantly maintained firmness of fruits, and showed higher $h^{\circ}$ value of fruits peel, ascorbic acid concentrations, total phenols content and antioxidant capacity values of LeConte pear fruits. Preharvest treatments by salicylic acid, L-arginine and L-tryptophan positively influenced postharvest fruit quality, salicylic acid at 200 ppm effectively maintained fruit quality during cold storage and shelf life.

Keywords: Pear, LeConte, Tryptophan, Salicylic acid, Arginine, Cold storage, Shelf life

\section{INTRODUCTION}

Pear is considered one of the most main deciduous fruit trees in all over the world. Le-Conte (Pyrus communis L. x Pyrus pyrifolia N.) is the widely prevalent cultivar of pear in Egypt. Enhancing pear productivity and improving fruit quality under the Egyptian environmental conditions is considered one of the main strategies for local market development. Yield of pear trees are significantly influenced by many factors, among these factors, self-incompatibility, excessive flower abscission, low fruit retention and susceptibility for many disorders during storage life (Sherif et al 2013).

Many amino acids are necessary for growth regulation, actually they participate in many processes in plant such as; protein synthesis, stress resistance, pollination and fruit development (Tegedera and Rentsch, 2010), one of preharvest effects is increasing free polyamine levels which decreasing abscission (Biasi et al 1988).

Arginine is a precursor for the synthesis of some polyamines and cytokinin production (Bagni and Tassoni, 2001), which mainly related to flower development, fruit set and fruit changes during maturity (Page et al 2012). Rugini et al (1986) suggested that sprays of L-arginine to olives whichever at full bloom or at the beginning of petal fall increased fruit set and quality, Mohseni et al (2017) illustrated that fruits of treated trees by arginine at concentrations of 250 or $500 \mu \mathrm{M}$ had better fruit weight, total soluble solids, sugar, titratable acidity, anthocyanin, phenol, and vitamin C. Babalar et al (2018) stated that arginine treatments showed significantly lower chilling injury symptoms and husk browning in pomegranate fruits during storage. 
In this regard, tryptophan is a precursor of indole-3-acetic acid, it resulted in increased fruit size and peel thickness (Pillitteri et al 2010). Furthermore, Hanfay et al (2012) revealed that tryptophan treatments improved the chemical composition such as pigments, total sugars, total soluble phenols, and total amino acids. Woijick et al (2016) found that pre-bloom tryptophan sprays enriched the concentrations of both calcium concentration in fruits and indole-3-acetic acid in fruitlets by about $18 \%$ and $230 \%$ in that order in comparison to control trees.

Salicylic acid is one of the endogenous plant growth regulators, has been reported to regulate and manage different physiological and metabolic activities in plants (Brar et al 2014), salicylic acid enhance plant stress resistance (Martinez et al 2004), improving fruit quality (Abdel Aziz et al 2017 and Abd-Elrazek et al 2013). In addition to its valuable effect in maintaining fruit firmness, reduced chilling injury incidence, and delayed membrane lipid peroxidation (Khademi and Ershadi, 2013), delayed fruit ripening through inhibiting ethylene biosynthesis thus maintains pre and post-harvest fruit quality (Srivastva and Dwivedi, 2000), through inhibit ripening hormone formation from 1-aminocyclopropane 1-carboxylic acid (Charles et al 1988). Reddy and Sharma (2016) found that salicylic acid was effective in extension of fruit shelf life, helped in maintaining the postharvest quality through better retention of total soluble solids content, total antioxidants and ascorbic acid in fruit tissues.

This study was conducted with the aim of enhancement fruit quality, storability, minimizing decay occurrence, browning and weight loss, and maintaining fruit nutritional value and antioxidants capacity of pear fruits cv. Le Conte during cold storage and shelf life using preharvest treatments of salicylic acid, arginine and tryptophan.

\section{MATERIALS AND METHODS}

\subsection{Fruit material and treatments}

This investigation was applied during two successive growing seasons (2015 and 2016) on pear trees cv. LeConte. Trees were fifteen years old, budded on Communis rootstock, planted at $5 \times 5 \mathrm{~m}$ apart and grown in loamy soil located in the Experimental Research Station affiliate of Faculty of Agriculture fields, Cairo University, Giza, Egypt. Trees were in regular growth, almost similar in vigor and received normal fertilization and cultural practices as scheduled in the program of the station.

The experiment was arranged in complete randomized block design using sixty-three trees represented seven treatments, every treatment involved three replicates, and three trees represent each replicate. Treatments were applied as foliar applications with the specified solutions until run off on trees at two stages, the first at full bloom stage whereas $70 \%$ of flower buds reached the stage of full open, the second at initial fruit set stage (3 weeks following full bloom stage). The conducted treatments included the following; arginine at $100 \mathrm{ppm}$, arginine at $200 \mathrm{ppm}$, tryptophan at $50 \mathrm{ppm}$, tryptophan at $100 \mathrm{ppm}$, salicylic acid at $100 \mathrm{ppm}$, salicylic acid at $200 \mathrm{ppm}$, in addition to sprayed with water as control, taking into consideration add of surfactants (Tween 20 at $0.1 \mathrm{ml}$ per liter of solution), in addition to arginine and tryptophan were used only as $\mathrm{L}$-arginine and Ltryptophan that are assimilated by plants, D-amino acids are not recognized by the enzymatic receptors and therefore can not take part in protein synthesis (Ortiz-Lopez et al 2000).

Fruits were harvested at maturity stage as the control fruits reached the estimated harvest date according to Kilany, (1982) depending in number of days after full bloom and different fruit characteristics, after that fruits were transported immediately to postharvest laboratory of Agricultural Systems Improvement Project, Faculty of Agriculture, Cairo University.

Fruits were dipped in distilled water with $2 \mathrm{mM}$ sodium hypochlorite for $2 \mathrm{~min}$ to reduce decay incidence. After that, all fruits were air-dried, fruits of each replicate were divided in groups for weight loss evaluation, decay follow up, and sampling for physical and chemical investigation, and packed in carton boxes and stored at $0^{\circ} \mathrm{C}$ and $90-95 \% \mathrm{RH}$ for 12 weeks (whereas weight loss percentage reach to about $5 \%$ ), then stored at $22^{\circ} \mathrm{C}$ to simulate marketing life for 12 days. Data were assessed before treatment and at 3 weeks intervals during cold storage, and after 6 and 12 days of shelf life using three replicates (5 fruits from each replicate) of each treatment. Collected samples were used to evaluate the following parameters. 

attributes of pear fruits cv. Le-Conte during cold storage and shelf life

\subsection{Fruit physical and physiological attributes}

\subsubsection{Weight loss}

Weight loss percentage was calculated according the following equation; (fruit initial weight - fruit weight at every sampling date) $\times 100 /$ fruit initial weight.

\subsubsection{Decay}

Decay percentage was evaluated as number of discarded fruits / total number of fruits $\times 100$, discarded fruits involved any signs of pathological, physiological disorders or discolouration defects.

\subsubsection{Firmness}

Fruit firmness was measured using a testing instrument (Mecmesin, force-torque test, England) equipped with $8 \mathrm{~mm}$ diameter probe, measurements were applied on different fruit sides according to Mitcham et al (2003), the obtained data were presented in $\mathrm{lb} /$ inch $^{2}$.

\subsubsection{Browning index}

Browning index was considered according to Veltman et al (2000), in every sampling date, Nine fruits of each replicate were cut and the area of the fruit flesh that was affected by brown core was compared to the total area, fruits were classified to 4 categories: $0=$ no browning, $1=<30 \%$ browning, $2=30-70 \%$ browning and $3=>70 \%$ browning. The browning index is the sum of the browning index score of the nine pears divided by 27 , and multiplied by $100 \%$, using the following formula; Browning index $=$ (sum of (browning category $\times$ fruits number of this category))/(the highest browning category $\times$ total fruits number) $\times 100$. In other words, browning index value of $0 \%$ indicate to no browning and $100 \%$ indicate to maximum browning.

\subsubsection{Instrumental colour}

Instrumental colour was measured in respect to CIE $L^{*} a^{*} b^{*}$ values on two opposed sides of each fruit objectively. Each measurement was taken at three locations for each fruit, using a Minolta CR400 chroma meter (Minolta, Osaka, Japan) according to McGuire (1992). The $L^{*}$ value was used as an indicator of brightness, a point to chromaticity on a green (-) to red (+) axis, $b^{*}$ indicate to yellow/blue rival colours with blue at negative $b^{*}$ values and yellow at positive $b^{*}$ values. Hue $\left(\mathrm{h}^{\circ}\right)$ is the common correspondence between colours positioned around a colour wheel (Nambi et al 2015), and chroma is the value of a colour's pureness, intensity or saturation.

\subsubsection{Respiration rate}

Respiration rate was measured using gas chromatography (Model 1450-Servomex 1400), fruit samples were incubated in 4-liter airtight glass jars for $24 \mathrm{hr}$ at the same experimental conditions according to McCollum et al (1993), and calculated as $\mathrm{ml}$ of $\mathrm{CO}_{2} / \mathrm{kg}$ fruit $/ \mathrm{hr}$

\subsection{Fruit chemical attributes}

\subsubsection{TSS (\%)}

TSS was measured using drops of the fruit juice, by hand refractometer according to Magwazaa and Opara (2015).

\subsubsection{Total phenols}

According to A.O.A.C. (2012) total phenolics were determined colourmetrically using Folin Denis reaction method at $765 \mathrm{~nm}$ as equivalent $\mathrm{mg}$ gallic acid per $100 \mathrm{~g} \mathrm{FWt} \mathrm{(fruit} \mathrm{weight).}$

\subsubsection{Ascorbic acid}

Ascorbic acid was estimated using titration method against 2,6 dicholorophenol-indophenol solution mentioned by Mazumdar and Majumder (2003), results were presented as mg ascorbic acid per $100 \mathrm{~g}$ fruit weight.

\subsubsection{Antioxidant capacity}

The analysis of antioxidants capacity was applied based on the determination of the free radical scavenging capacity of the extracts according to the procedure described by Brand-Williams et al (1995) at $515 \mathrm{~nm}$. The obtained data were stated as ascorbic acid equivalent antioxidant capacity.

\subsection{Statistical analysis}

All obtained data were analyzed as factorial randomized complete block design in nested arrangement with three replication. The variances between means were compared using LSD range test at the $5 \%$ level of probability in the two investigated seasons as described by Snedecor and Cochran (1989). 


\section{RESULTS AND DISCUSSION}

\subsection{Fruit physical and physiological attributes}

\subsubsection{Weight loss (\%)}

Changes in fruit weight is an important indication of fruit water content, nutritional value and fruit appearance. Tables $\mathbf{1}$ and 2 . declare the effect of L-arginine, L-tryptophan and salicylic acid treatments on weight loss percentage of Le-Conte pear fruits in 2015 and 2016 seasons. Weight loss increased progressively in all the conducted treatments during cold storage and shelf life period.

Salicylic acid treatments at 100 and 200 ppm showed the lowest weight loss percentages, compared with control that showed the highest signify- cant loss values, the differences were significant during cold storage conditions, but were nonsignificant during shelf life conditions in both investigation seasons.

In both seasons of this investigation, by the end of cold storage period at $0^{\circ} \mathrm{C}$ salicylic at $100 \mathrm{ppm}$ showed the lowest significant weight loss (5.65 and $5.52 \%$ ), while control showed the highest significant weight loss (7.77 and 7.02) in the first and the second season respectively. Moreover, by the end of shelf life period the lowest weight loss percentage appeared in fruits of treated trees by salicylic at $200 \mathrm{ppm}$ (5.01\%) and salicylic at $100 \mathrm{ppm}$ $(5.24 \%)$, whereas the highest weight loss percentage appeared in fruits of untreated trees as 6.82 and $5.81 \%$ in the first and the second season respectively.

Table 1. Effect of L-arginine, L-tryptophan and salicylic acid preharvest treatments on weight loss (\%) of Le-Conte pear fruits during cold storage and shelf life in 2015 season

\begin{tabular}{|c|c|c|c|c|c|c|c|c|c|c|}
\hline \multirow{2}{*}{ Treatments (A) } & \multicolumn{6}{|c|}{ Weeks of storage at $0^{\circ} \mathrm{C}(\mathrm{B})$} & \multicolumn{4}{|c|}{ Days of shelf life at $22^{\circ} \mathrm{C}(\mathrm{B})$} \\
\hline & Initial & 3 & 6 & 9 & 12 & Mean & Initial & 6 & 12 & Mean \\
\hline Arginine 100 ppm & 0.00 & 1.92 & 3.32 & 4.62 & 5.88 & 3.15 & 0.00 & 1.69 & 5.74 & 2.48 \\
\hline Arginine 200 ppm & 0.00 & 2.27 & 3.98 & 5.58 & 7.00 & 3.77 & 0.00 & 1.89 & 5.30 & 2.40 \\
\hline Tryptophan 50 ppm & 0.00 & 1.82 & 3.28 & 4.79 & 6.05 & 3.19 & 0.00 & 1.69 & 5.33 & 2.34 \\
\hline Tryptophan 100 ppm & 0.00 & 1.83 & 3.24 & 4.69 & 5.96 & 3.14 & 0.00 & 1.72 & 5.39 & 2.37 \\
\hline Salicylic 100 ppm & 0.00 & 1.74 & 3.10 & 4.42 & 5.65 & 2.98 & 0.00 & 1.52 & 5.48 & 2.33 \\
\hline Salicylic 200 ppm & 0.00 & 2.05 & 3.58 & 5.08 & 6.42 & 3.43 & 0.00 & 1.74 & 5.01 & 2.25 \\
\hline Control & 0.00 & 2.44 & 4.29 & 6.22 & 7.77 & 4.14 & 0.00 & 2.19 & 6.82 & 3.00 \\
\hline Mean & 0.00 & 2.01 & 3.54 & 5.06 & 6.39 & & 0.00 & 1.78 & 5.58 & \\
\hline L.S.D at 0.05 & \multicolumn{6}{|c|}{$(A)=0.32,(B)=0.27,(A \times B)=0.71$} & \multicolumn{4}{|c|}{$(A)=0.35,(B)=0.23,(A \times B)=0.60$} \\
\hline
\end{tabular}

Table 2. Effect of L-arginine, L-tryptophan and salicylic acid preharvest treatments on weight loss (\%) of Le-Conte pear fruits during cold storage and shelf life in 2016 season

\begin{tabular}{|c|c|c|c|c|c|c|c|c|c|c|}
\hline \multirow{2}{*}{ Treatments (A) } & \multicolumn{6}{|c|}{ Weeks of storage at $0^{\circ} \mathrm{C}(\mathrm{B})$} & \multicolumn{4}{|c|}{ Days of shelf life at $22^{\circ} \mathrm{C}(\mathrm{B})$} \\
\hline & Initial & 3 & 6 & 9 & 12 & Mean & Initial & 6 & 12 & Mean \\
\hline Arginine $100 \mathrm{ppm}$ & 0.00 & 2.00 & 3.48 & 4.92 & 6.18 & 3.32 & 0.00 & 1.66 & 5.51 & 2.39 \\
\hline Argin & 0.00 & 2.10 & 3.76 & 5.41 & 6.78 & 3.61 & 0.00 & 1.75 & 68 & .48 \\
\hline Tryptophan & 0.00 & 2.04 & 3.64 & 5.24 & 6.59 & 3.50 & 0.00 & 1.62 & 5.61 & 2.41 \\
\hline Tryptophan & 0.00 & 2.02 & 3.67 & 5.19 & 6.55 & 3.49 & 0.00 & 1.85 & 5.66 & 2.50 \\
\hline Salicylic 100 ppm & 0.00 & 1.69 & 2.94 & 4.37 & 5.52 & 2.90 & 0.00 & 1.61 & 5.24 & 2.28 \\
\hline Salicylic & 0.00 & 1.96 & 3.39 & 4.87 & 6.16 & 3.28 & 0.00 & 1.67 & 5.37 & 2.35 \\
\hline Control & 0.00 & 2.25 & 3.90 & 5.51 & 7.02 & 3.74 & 0.00 & 2.05 & 5.81 & 2.62 \\
\hline Mean & 0.00 & 2.01 & 3.54 & 5.07 & 6.40 & & 0.00 & 1.74 & 5.55 & \\
\hline L.S.D at 0.05 & \multicolumn{6}{|c|}{$(A)=0.45,(B)=0.38,(A \times B)=1.02$} & \multicolumn{4}{|c|}{$(A)=0.45,(B)=0.29,(A \times B)=0.79$} \\
\hline
\end{tabular}



attributes of pear fruits cv. Le-Conte during cold storage and shelf life

Evidently, weight loss increased gradually especially after raising the storage temperature during shelf life because of increased rates of respiration rate and evaporation of fruit cells (Mahajan et al 2013). Salicylic acid action might be due to salicylic effect on ethylene production and activity (Srivastva and Dwivedi, 2000), or salicylic role in free radicals production that reduce respiration rate (Shafie et al 2010), or changes in regulation of opening and closing of stomata (Champa et al 2015).

The obtained results were in agreement with Imran et al (2007) who declared that salicylic at $0.1 \mathrm{mM}$ achieved lower weight loss values in pear cv. Huang Kum. Also, Champa et al (2015) found that grapes treated by salicylic at 1.0, 1.5 and 2.0 $\mathrm{mM}$ attained lower weight loss rates compared with untreated fruits (control).

\subsubsection{Decay (\%)}

Decay percentage is considered the main judgment about the treatment validity to the commercial application. Data in Tables 3 and 4. present the impact of arginine, tryptophan and salicylic acid treatments on decay percentage of LeConte pear fruits in 2015 and 2016 seasons. Discarded fruits percentage increased gradually under all conditions. Salicylic at $200 \mathrm{ppm}$ minimized the rate of decay incidence to the lowest rates compared with untreated ones under cold storage and shelf life conditions in both seasons. After 12 weeks of storage at $0^{\circ} \mathrm{C}$, salicylic acid 100 and 200 $\mathrm{ppm}$ showed the lowest significant decay ratio $(0.93 \%)$ in both seasons, while untreated fruits reached to 7.41 and $6.48 \%$ in 2015 and 2016 seasons. Also, After 12 days of storage at $22^{\circ} \mathrm{C}$ salicylic at $200 \mathrm{ppm}$ showed the lowest significant decay incidence $(9.26 \%)$, while control showed the highest significant decay percentage (30.55 and $28.70 \%$ ) in both seasons of this study.

Table 3. Effect of L-arginine, L-tryptophan and salicylic acid preharvest treatments on decay percentage of Le-Conte pear fruits during cold storage and shelf life in 2015 season

\begin{tabular}{|c|c|c|c|c|c|c|c|c|c|c|}
\hline \multirow{2}{*}{ Treatments (A) } & \multicolumn{6}{|c|}{ Weeks of storage at $0^{\circ} \mathrm{C}$ (B) } & \multicolumn{4}{|c|}{ Days of shelf life at $22^{\circ} \mathrm{C}$ (B) } \\
\hline & Initial & 3 & 6 & 9 & 12 & Mean & Initial & 6 & 12 & Mean \\
\hline Arginine $100 \mathrm{ppm}$ & 0.00 & 0.00 & 0.00 & 0.00 & 1.85 & 0.37 & 0.00 & 9.26 & 11.11 & 6.79 \\
\hline Arginine 200 ppm & 0.00 & 0.00 & 0.93 & 2.78 & 3.71 & 1.48 & 0.00 & 11.11 & 15.74 & 8.95 \\
\hline Tryptophan 50 ppm & 0.00 & 0.00 & 0.00 & 0.00 & 1.85 & 0.37 & 0.00 & 10.18 & 13.89 & 8.02 \\
\hline Tryptophan 100 ppm & 0.00 & 0.00 & 0.00 & 0.93 & 2.78 & 0.74 & 0.00 & 12.04 & 16.67 & 9.57 \\
\hline Salicylic 100 ppm & 0.00 & 0.00 & 0.00 & 0.00 & 0.93 & 0.19 & 0.00 & 7.41 & 12.04 & 6.48 \\
\hline Salicylic 200 ppm & 0.00 & 0.00 & 0.00 & 0.00 & 0.93 & 0.19 & 0.00 & 4.63 & 9.26 & 4.63 \\
\hline Control & 0.00 & 0.00 & 1.85 & 4.63 & 7.41 & 2.78 & 0.00 & 20.37 & 30.55 & 16.97 \\
\hline Mean & 0.00 & 0.00 & 0.40 & 1.19 & 2.78 & & 0.00 & 10.71 & 15.61 & \\
\hline L.S.D at 0.05 & \multicolumn{6}{|c|}{$(A)=1.07,(B)=0.91,(A \times B)=2.39$} & \multicolumn{4}{|c|}{$(A)=2.25,(B)=1.47,(A \times B)=3.9$} \\
\hline
\end{tabular}

Table 4. Effect of L-arginine, L-tryptophan and salicylic acid preharvest treatments on decay percentage of Le-Conte pear fruits during cold storage and shelf life in 2016 season

\begin{tabular}{|c|c|c|c|c|c|c|c|c|c|c|}
\hline \multirow{2}{*}{ Treatments (A) } & \multicolumn{6}{|c|}{ Weeks of storage at $0^{\circ} \mathrm{C}(\mathrm{B})$} & \multicolumn{4}{|c|}{ Days of shelf life at $22^{\circ} \mathrm{C}(\mathrm{B})$} \\
\hline & Initial & 3 & 6 & 9 & 12 & Mean & Initial & 6 & 12 & Mean \\
\hline Arginine 100 ppm & 0.00 & 0.00 & 0.00 & 0.00 & 0.93 & 0.19 & 0.00 & 9.26 & 11.11 & 6.79 \\
\hline Arginine $200 \mathrm{ppm}$ & 0.00 & 0.00 & 0.00 & 1.85 & 3.71 & 1.11 & 0.00 & 12.04 & 14.82 & 8.95 \\
\hline Tryptophan 50 ppm & 0.00 & 0.00 & 0.00 & 0.00 & 1.85 & 0.37 & 0.00 & 10.18 & 13.89 & 8.02 \\
\hline Tryptophan 100 ppm & 0.00 & 0.00 & 0.00 & 0.93 & 2.78 & 0.74 & 0.00 & 11.11 & 15.74 & 8.95 \\
\hline Salicylic 100 ppm & 0.00 & 0.00 & 0.00 & 0.00 & 0.93 & 0.19 & 0.00 & 7.41 & 12.04 & 6.48 \\
\hline Salicylic 200 ppm & 0.00 & 0.00 & 0.00 & 0.00 & 0.93 & 0.19 & 0.00 & 5.56 & 9.26 & 4.94 \\
\hline Control & 0.00 & 0.00 & 0.93 & 4.63 & 6.48 & 2.41 & 0.00 & 19.45 & 28.70 & 16.05 \\
\hline Mean & 0.00 & 0.00 & 0.13 & 1.06 & 2.51 & & 0.00 & 10.71 & 15.08 & \\
\hline L.S.D at 0.05 & \multicolumn{6}{|c|}{$(A)=0.96,(B)=0.81,(A \times B)=2.15$} & \multicolumn{4}{|c|}{$(A)=2.19,(B)=1.43,(A \times B)=3.79$} \\
\hline
\end{tabular}


No doubt, the different changes in physiological processes in fruit cells and exposure to surrounding conditions and microorganisms led to increasing loss in fruit quality and discarded fruits with storage period prolongation. Anyhow, salicylic acid treatments at 100 and 200 ppm were effective in minimize this loss, Khademi and Ershadi (2013) approved this effect of salicylic acid in peaches and Luo et al (2011) in plum fruits by reducing chilling injury disorders occurrence, and membrane lipid oxidation,. Ahmed et al (2013) mentioned that salicylic acid at 8 and $9 \mathrm{mM}$ reduced fruit rot and chilling injury in orange cvs. Lane Late and Valencia Late.

In addition to, Champa et al (2015) reported significant decrement in decay percentage in grape treated by salicylic at 1.5 and $2.0 \mathrm{mM}$. Yao and Tian (2005) cited that preharvest salicylic acid treatments accelerate many enzymes such as peroxidase that play a defense role againast many diseases.

\subsubsection{Firmness (lb/inch $\left.{ }^{2}\right)$}

Fruit firmness is an indicator to fruit quality, chemical changes in cell wall, and storage life. Data presented in Tables 5 and $\mathbf{6}$. Declare the effect of different applied acids treatments on firmness of pear fruits cv. Le-Conte in both seasons, pear fruit hardness decreased gradually with storage life prolongation. Treatment of salicylic acid at 200 ppm significantly maintained pear fruits firmness, on the other hand the decrement of firmness was earlier in untreated ones.

Firmness reached to 17.58 and $17.66{\mathrm{lb} / \mathrm{inch}^{2}}^{2}$ in fruits treated by salicylic at $200 \mathrm{ppm}$, while it reached to 16.35 and $16.80 \mathrm{lb} /$ inch $^{2}$ in control after 12 weeks of cold storage of this investigation. In the same way, firmness reached to 7.02 and 7.03 $\mathrm{lb} / \mathrm{inch}^{2}$ in fruits treated by salicylic acid at 200 $\mathrm{ppm}$, while it reached to 6.17 and $6.24 \mathrm{lb} / \mathrm{inch}^{2}$ in control after 12 days of shelf life in both seasons of this work.

Table 5. Effect of arginine, tryptophan and salicylic acid treatments on firmness (lb/inch $\left.{ }^{2}\right)$ of Le-Conte pear fruits during cold storage and shelf life in 2015 season

\begin{tabular}{|c|c|c|c|c|c|c|c|c|c|c|}
\hline \multirow{2}{*}{ Treatments (A) } & \multicolumn{6}{|c|}{ Weeks of storage at $0^{\circ} \mathrm{C}(\mathrm{B})$} & \multicolumn{4}{|c|}{ Days of shelf life at $22^{\circ} \mathrm{C}(\mathrm{B})$} \\
\hline & Initial & 3 & 6 & 9 & 12 & Mean & Initial & 6 & 12 & Mean \\
\hline Arginine $100 \mathrm{ppm}$ & 26.27 & 21.60 & 20.74 & 19.34 & 17.23 & 21.03 & 17.23 & 12.07 & 6.84 & 12.05 \\
\hline Arginine 200 ppm & 24.40 & 20.81 & 20.29 & 19.49 & 16.97 & 20.39 & 16.97 & 11.67 & 6.55 & 11.73 \\
\hline Tryptophan 50 ppm & 25.71 & 21.43 & 20.86 & 19.52 & 17.02 & 20.91 & 17.02 & 11.83 & 6.71 & 11.85 \\
\hline Tryptophan 100 ppm & 23.40 & 20.77 & 20.11 & 19.44 & 16.84 & 20.11 & 16.84 & 11.53 & 6.47 & 11.62 \\
\hline Salicylic 100 ppm & 26.34 & 21.68 & 21.14 & 19.81 & 17.34 & 21.26 & 17.34 & 12.00 & 6.92 & 12.09 \\
\hline Salicylic 200 ppm & 26.71 & 22.33 & 21.82 & 19.62 & 17.58 & 21.61 & 17.58 & 12.13 & 7.02 & 12.24 \\
\hline Control & 21.73 & 19.43 & 18.14 & 17.34 & 16.35 & 18.60 & 16.35 & 11.03 & 6.17 & 11.18 \\
\hline Mean & 24.94 & 21.15 & 20.44 & 19.22 & 17.05 & & 17.05 & 11.75 & 6.67 & \\
\hline L.S.D at 0.05 & \multicolumn{6}{|c|}{$(A)=0.98,(B)=0.83,(A \times B)=2.20$} & \multicolumn{4}{|c|}{$\begin{array}{c}(A)=0.33,(B)=0.22,(A \times B)= \\
0.57\end{array}$} \\
\hline
\end{tabular}

Table 6. Effect of arginine, tryptophan and salicylic acid treatments on firmness (lb/inch $\left.{ }^{2}\right)$ of Le-Conte pear fruits during cold storage and shelf life in 2016 season

\begin{tabular}{|c|c|c|c|c|c|c|c|c|c|c|}
\hline \multirow{2}{*}{ Treatments (A) } & \multicolumn{6}{|c|}{ Weeks of storage at $0^{\circ} \mathrm{C}(\mathrm{B})$} & \multicolumn{4}{|c|}{ Days of shelf life at $22^{\circ} \mathrm{C}(\mathrm{B})$} \\
\hline & Initial & 3 & 6 & 9 & 12 & Mean & Initial & 6 & 12 & Mean \\
\hline Arginine 100 ppm & 25.43 & 21.70 & 20.21 & 18.18 & 17.44 & 20.59 & 17.44 & 11.67 & 6.92 & 12.01 \\
\hline Arginine 200 ppm & 26.23 & 21.32 & 19.85 & 18.07 & 17.26 & 20.54 & 17.26 & 11.54 & 6.59 & 11.80 \\
\hline Tryptophan 50 ppm & 24.13 & 21.62 & 20.13 & 18.16 & 17.42 & 20.29 & 17.42 & 11.83 & 6.86 & 12.04 \\
\hline Tryptophan 100 ppm & 23.37 & 21.35 & 19.81 & 18.01 & 17.20 & 19.95 & 17.20 & 11.70 & 6.61 & 11.84 \\
\hline Salicylic 100 ppm & 26.10 & 21.69 & 20.19 & 18.20 & 17.47 & 20.73 & 17.47 & 11.93 & 6.98 & 12.12 \\
\hline Salicylic 200 ppm & 26.50 & 21.82 & 20.32 & 18.31 & 17.66 & 20.92 & 17.66 & 12.00 & 7.03 & 12.23 \\
\hline Control & 23.07 & 20.57 & 19.13 & 17.60 & 16.80 & 19.43 & 16.80 & 11.16 & 6.24 & 11.40 \\
\hline Mean & 24.98 & 21.44 & 19.95 & 18.08 & 17.32 & & 17.32 & 11.69 & 6.75 & \\
\hline L.S.D at 0.05 & \multicolumn{6}{|c|}{$(A)=0.62,(B)=0.52,(A \times B)=1.38$} & \multicolumn{4}{|c|}{$\begin{array}{c}(A)=0.26,(B)=0.17,(A \times B)= \\
0.45\end{array}$} \\
\hline
\end{tabular}



attributes of pear fruits cv. Le-Conte during cold storage and shelf life

Firmness of climacteric fruits is rapidly lost due to the peak in ethylene production that related to cell wall degradation enzymes (Bonghi et al 1998). All the conducted treatments showed higher firmness values than control, in relation to arginine and tryptophan effects Berta et al (1997) reported that polyamines and ethylene have inconsistent properties on senescence, in other words increasing polyamines in fruits after arginine and tryptophan treatments resulted in lower softening.

The priority of salicylic treatment was similar to previous investigations; Valero et al (2011) and Ahmed et al (2013) found that pre-harvest salicylic acid treatments resulted in higher firmness compared with control. Valero et al (2011) attributed the effect of salicylic acid to suppression enzymes such as pectin esterase, pectin methylesterase and polygalacturonase which responsible for wall degradation, Khademi and Ershadi, (2013) reported that salicylic acid maintained fruit firmness by slow down membrane lipid peroxidation.

Kazami et al (2011) mentioned that, salicylic acid decrease activity of 1-aminocyclopropane 1 carboxylic acid oxidase enzyme that resulted in lower conversion of 1-aminocyclopropane 1- carboxylic acid to ethylene, consequently delay ripening and over ripening changes.

\subsubsection{Browning index}

The changes in browning index of Le-Conte pear fruits in response to the conducted treatments are presented in Tables 7 and $\mathbf{8}$. Flesh browning increased gradually by the time, salicylic acid at 200 ppm was effective in alleviating browning compared with untreated ones under all applied conditions.

By the end of cold storage period, salicylic acid at 200 ppm showed the lowest significant browning index (2.47), while control showed the highest significant browning index (9.87) in both seasons. Also, by the end of shelf life period, salicylic 200 ppm showed the lowest significant browning index (14.81 and 9.87), while control showed the highest significant browning index (24.69 and 23.45) in both seasons.

Browning is one of the limiting factors for pear storage for a long time, browning not only reduces the visual quality of fruits but also results in undesirable changes in flavour and nutrition loss (Luo and Barbosa-Canovas, 1997).

Table 7. Effect of arginine, tryptophan and salicylic acid preharvest treatments on browning index of LeConte pear fruits during cold storage and shelf life in 2015 season

\begin{tabular}{|c|c|c|c|c|c|c|c|c|c|c|}
\hline \multirow{2}{*}{ Treatments (A) } & \multicolumn{6}{|c|}{ Weeks of storage at $0^{\circ} \mathrm{C}(\mathrm{B})$} & \multicolumn{4}{|c|}{ Days of shelf life at $22^{\circ} \mathrm{C}(\mathrm{B})$} \\
\hline & Initial & 3 & 6 & 9 & 12 & Mean & Initial & 6 & 12 & Mean \\
\hline Arginine $100 \mathrm{ppm}$ & 0.00 & 0.00 & 0.00 & 1.23 & 3.70 & 0.99 & 3.70 & 7.40 & 16.04 & 9.05 \\
\hline Arginine 200 ppm & 0.00 & 0.00 & 1.23 & 2.47 & 6.17 & 1.97 & 6.17 & 9.87 & 18.51 & 11.52 \\
\hline Tryptophan 50 ppm & 0.00 & 0.00 & 0.00 & 1.23 & 3.70 & 0.99 & 3.70 & 7.40 & 17.28 & 9.46 \\
\hline Tryptophan 100 ppm & 0.00 & 0.00 & 0.00 & 2.47 & 4.93 & 1.48 & 4.93 & 12.34 & 17.28 & 11.52 \\
\hline Salicylic 100 ppm & 0.00 & 0.00 & 0.00 & 1.23 & 3.70 & 0.99 & 3.70 & 7.40 & 16.04 & 9.05 \\
\hline Salicylic 200 ppm & 0.00 & 0.00 & 0.00 & 0.00 & 2.47 & 0.49 & 2.47 & 4.94 & 14.81 & 7.40 \\
\hline Control & 0.00 & 2.47 & 3.70 & 6.17 & 9.87 & 4.44 & 9.87 & 13.58 & 24.69 & 16.05 \\
\hline Mean & 0.00 & 0.35 & 0.70 & 2.11 & 4.93 & & 4.93 & 8.99 & 17.81 & \\
\hline L.S.D at 0.05 & \multicolumn{6}{|c|}{$(A)=1.40,(B)=1.18,(A \times B)=3.13$} & \multicolumn{4}{|c|}{$\begin{array}{c}(A)=3.70,(B)=2.42,(A \times B)= \\
6.41\end{array}$} \\
\hline
\end{tabular}


Table 8. Effect of arginine, tryptophan and salicylic acid preharvest treatments on browning index of LeConte pear fruits during cold storage and shelf life in 2016 season

\begin{tabular}{|c|c|c|c|c|c|c|c|c|c|c|}
\hline \multirow{2}{*}{ Treatments (A) } & \multicolumn{6}{|c|}{ Weeks of storage at $0^{\circ} \mathrm{C}(\mathrm{B})$} & \multicolumn{4}{|c|}{ Davs of shelf life at $22^{\circ} \mathrm{C}(\mathrm{B})$} \\
\hline & nitial & 3 & 6 & 9 & 12 & Mean & Initial & 6 & 12 & Mean \\
\hline Arginine & 0.00 & & & 1.23 & 6.17 & 1.48 & 6.17 & 13.58 & 18.51 & 12.75 \\
\hline & & & & 3 & & 2.2 & & 31 & 19.75 & 13.99 \\
\hline Trypto & 00 & & & 1.23 & 4.93 & & & & 16. & 12.34 \\
\hline & & & & 2.47 & & & & & & 13.16 \\
\hline & 0.00 & & & 1.23 & 3.7 & 0.5 & 0 & & 12. & 8.23 \\
\hline Salicylic 200 ppm & 0.00 & 0.00 & 0.00 & 1.23 & 2.47 & 0.74 & 2.47 & 7.40 & 9.87 & 6.58 \\
\hline Control & 0.00 & 1.23 & 2.47 & 7.40 & 9.87 & 4.19 & 9.87 & 17.28 & 23.45 & 16.87 \\
\hline & 0.00 & 0.18 & 0.53 & 2.64 & 5.82 & & 5.82 & 13.05 & 17.10 & \\
\hline L.S.D at 0.05 & \multicolumn{6}{|c|}{$(A)=1.54,(B)=1.30,(A \times B)=3.45$} & \multicolumn{4}{|c|}{$\begin{array}{c}(A)=2.81,(B)=1.84,(A \times B)= \\
4.87\end{array}$} \\
\hline
\end{tabular}

Amiot et al (1992) reported that browning of pear fruits was related to the enzymes effect in presence of chlorogenic acid in the fruit, also the degree of browning of pear fruits is depending on cultivar, maturity stage at harvest, and storage conditions (Amiot et al 1995). Veltman et al (1999) reported that browning of pear fruits is affected by ascorbic acid content, in this way Waliszewski et al (2007) approved that oxidation of phenolic compound by polyphenol oxidase enzyme is the main reason of browning. The obtained data are in agreement with those investigations, salicylic treatments maintained ascorbic acid and phenols levels. Moreover, Tareen et al (2012) declared that the favorable effect of salicylic acid on alleviate browning is related to reduction of polyphenol oxidase enzyme activity.

\subsubsection{Instrumental colour (hue angle value)}

Tables 9 and 10. present the changes that occurred in $\mathrm{h}^{\circ}$ value of Le-Conte pear fruits peel in response to arginine, tryptophan and salicylic treatments in 2015 and 2016 seasons, hue angle decreased gradually with prolonging storage life.

Salicylic at 200 ppm significantly showed the highest $h$ value, while control showed the lowest significant $h^{\circ}$ value during cold storage and shelf life.

Data analysis showed that after 12 weeks of cold storage, salicylic acid at $200 \mathrm{ppm}$ showed the highest significant $h^{\circ}$ values (102.13 and 106.66) while control showed the lowest significant $h^{\circ}$ values (100.28 and 104.27) in 2015 and 2016 seasons. By the end of shelf life salicylic acid at 200 ppm showed the highest significant $h^{\circ}$ value (101.31 and 102.55) while control showed the lowest significant $h^{\circ}$ value (99.08 and 99.75).

Table 9. Effect of arginine, tryptophan and salicylic acid preharvest treatments on $\mathrm{h}^{\circ}$ value of Le-Conte pear fruits peel during cold storage and shelf life in 2015 season

\begin{tabular}{|c|c|c|c|c|c|c|c|c|c|c|}
\hline \multirow{2}{*}{ Treatments (A) } & \multicolumn{6}{|c|}{ Weeks of storage at $0^{\circ} \mathrm{C}(\mathrm{B})$} & \multicolumn{4}{|c|}{ Days of shelf life at $22^{\circ} \mathrm{C}$ (B) } \\
\hline & Initial & 3 & 6 & 9 & 12 & Mean & Initial & 6 & 12 & Mean \\
\hline Arginine 100 ppm & 109.34 & 107.61 & 104.40 & 102.61 & 101.82 & 105.16 & 101.82 & 101.21 & 100.38 & 101.14 \\
\hline Arginine 200 ppm & 109.96 & 107.17 & 104.67 & 101.50 & 100.74 & 104.81 & 100.74 & 100.61 & 100.30 & 100.55 \\
\hline Tryptophan 50 ppm & 109.08 & 106.17 & 104.79 & 102.66 & 101.80 & 104.90 & 101.80 & 100.42 & 100.13 & 100.78 \\
\hline Tryptophan 100 ppm & 109.28 & 106.93 & 104.39 & 101.41 & 100.67 & 104.54 & 100.67 & 100.32 & 100.11 & 100.37 \\
\hline Salicylic 100 ppm & 110.33 & 108.37 & 104.90 & 102.77 & 101.95 & 105.66 & 101.95 & 101.63 & 101.13 & 101.57 \\
\hline Salicylic 200 ppm & 111.74 & 109.79 & 105.71 & 103.69 & 102.13 & 106.61 & 102.13 & 101.61 & 101.31 & 101.68 \\
\hline Control & 107.60 & 104.03 & 103.71 & 100.61 & 100.28 & 103.24 & 100.28 & 99.68 & 99.08 & 99.68 \\
\hline Mean & 109.62 & 107.15 & 104.65 & 102.18 & 101.34 & & 101.34 & 100.78 & 100.35 & \\
\hline L.S.D at 0.05 & \multicolumn{6}{|c|}{$(A)=1.80,(B)=1.52,(A \times B)=4.03$} & \multicolumn{4}{|c|}{$\begin{array}{c}(A)=1.25,(B)=0.82,(A \times B)= \\
2.17\end{array}$} \\
\hline
\end{tabular}



attributes of pear fruits cv. Le-Conte during cold storage and shelf life

Table 10. Effect of arginine, tryptophan and salicylic acid preharvest treatments on $h^{\circ}$ value of Le-Conte pear fruits peel during cold storage and shelf life in 2016 season

\begin{tabular}{|c|c|c|c|c|c|c|c|c|c|c|}
\hline \multirow{2}{*}{ Treatments (A) } & \multicolumn{6}{|c|}{ Weeks of storage at $0^{\circ} \mathrm{C}(\mathrm{B})$} & \multicolumn{4}{|c|}{ Days of shelf life at $22^{\circ} \mathrm{C}$ (B) } \\
\hline & Initial & 3 & 6 & 9 & 12 & Mean & Initial & 6 & 12 & Mean \\
\hline Arginine 100 ppm & 110.21 & 109.22 & 108.53 & 108.38 & 105.55 & 108.38 & 105.55 & 103.21 & 101.38 & 103.38 \\
\hline Arginine 200 ppm & 108.72 & 107.81 & 107.18 & 105.31 & 104.58 & 106.72 & 104.58 & 103.95 & 102.28 & 103.60 \\
\hline Tryptophan 50 ppm & 110.06 & 108.20 & 107.66 & 107.20 & 104.73 & 107.57 & 104.73 & 102.09 & 100.98 & 102.60 \\
\hline Tryptophan 100 ppm & 110.85 & 109.61 & 107.12 & 105.66 & 105.36 & 107.72 & 105.36 & 101.67 & 100.67 & 102.57 \\
\hline Salicylic 100 ppm & 110.26 & 108.64 & 108.40 & 106.44 & 106.36 & 108.02 & 106.36 & 104.37 & 102.46 & 104.40 \\
\hline Salicylic 200 ppm & 111.49 & 109.45 & 108.35 & 107.41 & 106.66 & 108.67 & 106.66 & 104.38 & 102.55 & 104.53 \\
\hline Control & 108.19 & 107.32 & 106.75 & 105.96 & 104.27 & 106.50 & 104.27 & 100.35 & 99.75 & 101.46 \\
\hline Mean & 109.97 & 108.61 & 107.71 & 106.62 & 105.36 & & 105.36 & 102.86 & 101.44 & \\
\hline L.S.D at 0.05 & \multicolumn{6}{|c|}{$(A)=2.39,(B)=2.02,(A \times B)=5.35$} & \multicolumn{4}{|c|}{$\begin{array}{c}(A)=2.87,(B)=1.88,(A \times B)= \\
4.98\end{array}$} \\
\hline
\end{tabular}

Values of $h^{\circ}$ declare the colour changes from green to yellow of peel, according to Taiz and Zeiger (2010) ethylene is the responsible for ripening changes in fruit including colour changes by manage pigments synthesis, The green colour of the unripe fruit is due to the existence of chlorophylls, and the increase of different colours during ripening is due to the disappearance of these pigments and the synthesis of carotenoids, in this way salicylic delay colour changes. Imran et al., (2007) obtained similar results in pear cv. Huang Kum treated by salicylic at $0.1 \mathrm{mM}$, in addition to Champa et al (2015) in grapes cv. Flame treated by salicylic at 1.5 and $2.0 \mathrm{mM}$.

\subsubsection{Respiration rate $(\mathrm{ml} \mathrm{CO} / \mathrm{kg}$ fruit / hr)}

Tables 11 and 12. illustrate the effect of arginine, tryptophan and salicylic acid treatments on respiration rate $(\mathrm{ml} \mathrm{CO} / \mathrm{kg}$ fruit / hr) of Le-Conte pear fruits in 2015 and 2016 seasons, respiration rate increased gradually after 3 weeks of storage at $0^{\circ} \mathrm{C}$. Pear is classified as climacteric fruits, which characterized by increasing in its ethylene and respiration rate in certain time of its life (Rhodes, 1980). Salicylic at $200 \mathrm{ppm}$ showed the lowest significant respiration rates, while control showed the highest significant respiration rates during the estimated storage time.

By the end of storage period control showed the highest significant respiration rate (5.85 and $5.91 \mathrm{ml} \mathrm{CO}_{2} / \mathrm{kg}$ fruit / hr), while salicylic $200 \mathrm{ppm}$ showed the lowest significant respiration rate (5.64 and $5.41 \mathrm{ml} \mathrm{CO}_{2} / \mathrm{kg}$ fruit / hr) in the first and the second season respectively. Moreover, by the end of shelf life period control showed the highest respiration rates $\left(11.49\right.$ and $11.89 \mathrm{ml} \mathrm{CO}_{2} / \mathrm{kg}$ fruit / $\mathrm{hr}$ ), while salicylic $200 \mathrm{ppm}$ showed the lowest respiration rates $\left(11.05\right.$ and $10.88 \mathrm{ml} \mathrm{CO}_{2} / \mathrm{kg}$ fruit $/ \mathrm{hr}$ ) in the first and the second season respectively, taking into consideration the differences between all treatments were non significant in this date in the second season.

Srivastava and Dwivedi (2000) suggested that salicylic acid decrease ethylene biosynthesis and activity, which led to lower respiration rate, salicylic acid inhibited ethylene formation from 1aminocyclopropane 1-carboxylic acid (Babalar et al 2007). Moreover, Shafie et al (2010) reported that salicylic acid produces free radicals that decrease respiration rate. 
Table 11. Effect of arginine, tryptophan and salicylic acid preharvest treatments on respiration rate $(\mathrm{ml}$ $\mathrm{CO}_{2} / \mathrm{kg}$ fruit / hr) of Le-Conte pear fruits during cold storage and shelf life in 2015 season

\begin{tabular}{|c|c|c|c|c|c|c|c|c|c|c|}
\hline \multirow{2}{*}{ Treatments (A) } & \multicolumn{6}{|c|}{ Weeks of storage at $0^{\circ} \mathrm{C}(\mathrm{B})$} & \multicolumn{4}{|c|}{ Days of shelf life at $22^{\circ} \mathrm{C}(\mathrm{B})$} \\
\hline & Initial & 3 & 6 & 9 & 12 & Mean & Initial & 6 & 12 & Mean \\
\hline Arginine 100 ppm & 5.47 & 3.73 & 3.80 & 4.47 & 5.74 & 4.64 & 5.74 & 7.08 & 11.08 & 7.97 \\
\hline Arginine 200 ppm & 5.58 & 3.77 & 3.84 & 4.50 & 5.79 & 4.70 & 5.79 & 7.13 & 11.22 & 8.05 \\
\hline Tryptophan 50 ppm & 5.64 & 3.78 & 3.82 & 4.49 & 5.77 & 4.70 & 5.77 & 7.14 & 11.12 & 8.01 \\
\hline Tryptophan 100 ppm & 5.83 & 3.80 & 3.88 & 4.55 & 5.80 & 4.77 & 5.80 & 7.23 & 11.16 & 8.06 \\
\hline Salicylic 100 ppm & 5.73 & 3.78 & 3.89 & 4.27 & 5.68 & 4.67 & 5.68 & 7.03 & 11.11 & 7.94 \\
\hline Salicylic 200 ppm & 5.70 & 3.70 & 3.81 & 4.33 & 5.64 & 4.64 & 5.64 & 6.99 & 11.05 & 7.90 \\
\hline Control & 6.40 & 3.84 & 3.92 & 4.59 & 5.85 & 4.92 & 5.85 & 7.69 & 11.49 & 8.34 \\
\hline Mean & 5.76 & 3.77 & 3.85 & 4.46 & 5.75 & & 5.75 & 7.19 & 11.17 & \\
\hline L.S.D at 0.05 & \multicolumn{6}{|c|}{$(A)=0.31,(B)=0.26,(A \times B)=0.70$} & \multicolumn{4}{|c|}{$\begin{array}{c}(A)=0.31,(B)=0.20,(A \times B)= \\
0.54\end{array}$} \\
\hline
\end{tabular}

Table 12. Effect of arginine, tryptophan and salicylic acid preharvest treatments on respiration rate $(\mathrm{ml}$ $\mathrm{CO}_{2} / \mathrm{kg}$ fruit / hr) of Le-Conte pear fruits during cold storage and simulated marketing life in 2016 season

\begin{tabular}{|c|c|c|c|c|c|c|c|c|c|c|}
\hline \multirow{2}{*}{ Treatments (A) } & \multicolumn{6}{|c|}{ Weeks of storage at $0^{\circ} \mathrm{C}(\mathrm{B})$} & \multicolumn{4}{|c|}{ Days of shelf life at $22^{\circ} \mathrm{C}(\mathrm{B})$} \\
\hline & Initial & 3 & 6 & 9 & 12 & Mean & Initial & 6 & 12 & Mean \\
\hline Arginine $100 \mathrm{ppm}$ & 5.43 & 3.89 & 3.87 & 4.30 & 5.54 & 4.61 & 5.54 & 7.25 & 11.14 & 7.98 \\
\hline Arginine 200 ppm & 5.56 & 3.80 & 3.82 & 4.42 & 5.62 & 4.64 & 5.62 & 7.38 & 11.34 & 8.11 \\
\hline Tryptophan 50 ppm & 5.64 & 3.85 & 3.85 & 4.39 & 5.60 & 4.66 & 5.60 & 7.31 & 11.23 & 8.05 \\
\hline Tryptophan 100 ppm & 5.84 & 3.97 & 3.91 & 4.48 & 5.67 & 4.77 & 5.67 & 7.44 & 11.48 & 8.20 \\
\hline Salicylic 100 ppm & 5.63 & 3.87 & 3.95 & 4.20 & 5.38 & 4.61 & 5.38 & 7.06 & 10.94 & 7.79 \\
\hline Salicylic 200 ppm & 5.62 & 3.82 & 3.85 & 4.24 & 5.41 & 4.59 & 5.41 & 7.04 & 10.88 & 7.78 \\
\hline Control & 6.33 & 3.92 & 3.96 & 4.41 & 5.91 & 4.90 & 5.91 & 7.77 & 11.89 & 8.52 \\
\hline Mean & 5.72 & 3.87 & 3.89 & 4.35 & 5.59 & & 5.59 & 7.32 & 11.27 & \\
\hline L.S.D at 0.05 & \multicolumn{6}{|c|}{$(A)=0.30,(B)=0.25,(A \times B)=0.68$} & \multicolumn{4}{|c|}{$\begin{array}{c}(A)=0.41,(B)=0.27,(A \times B)= \\
0.71\end{array}$} \\
\hline
\end{tabular}

Lu et al (2011) found that preharvest salicylic treatment at $2 \mathrm{mM}$ effectively decreased respiration rate, in the same way Khedr, (2016) found similar data in mango cv. Keitt treated by salicylic at 1 and $2 \mathrm{mM}$, which significantly decreased respiration levels compared with control.

\subsection{Fruit chemical attributes}

\subsubsection{TSS (\%)}

TSS is an important indicator to fruit taste and the fruit general condition, Tables 13 and 14 illustrate the effect of arginine, tryptophan and salicylic acid treatments on TSS of Le-Conte pear fruits in both seasons. TSS increased gradually during cold storage, but there were different trends in treatments during shelf life at $22^{\circ} \mathrm{C}$.
Tryptophan at $100 \mathrm{ppm}$ showed the highest significant TSS values, while salicylic at $200 \mathrm{ppm}$ showed the lowest significant TSS values during storage at 0 and $22^{\circ} \mathrm{C}$. After 12 weeks of cold storage conditions at $0^{\circ} \mathrm{C}$, tryptophan 100 ppm showed the highest significant TSS (17.18 and 17.11\%) while salicylic at $200 \mathrm{ppm}$ showed the lowest significant TSS (16.61 and 16.83\%) in 2015 and 2016 respectively.

By the end of simulated shelf life, salicylic 200 ppm showed the highest significant TSS (17.34\%) in the first season, and tryptophan at $100 \mathrm{ppm}$ $(17.23 \%)$ in the second season, while control showed the lowest significant TSS as 16.93 and $16.99 \%$ in the first and the second season respectively. 
Khedr

Table 13. Effect of arginine, tryptophan and salicylic acid treatments on TSS percentage of LeConte pear fruits during cold storage and shelf life in 2015 season

\begin{tabular}{|c|c|c|c|c|c|c|c|c|c|c|}
\hline \multirow{2}{*}{ Treatments (A) } & \multicolumn{6}{|c|}{ Weeks of storage at $0^{\circ} \mathrm{C}(\mathrm{B})$} & \multicolumn{4}{|c|}{ Days of shelf life at $22^{\circ} \mathrm{C}(\mathrm{B})$} \\
\hline & Initial & 3 & 6 & 9 & 12 & Mean & Initial & 6 & 12 & Mean \\
\hline Arginine $100 \mathrm{ppm}$ & 13.08 & 13.38 & 15.08 & 15.41 & 16.82 & 14.75 & 16.82 & 17.24 & 17.27 & 17.11 \\
\hline Argil & 13.25 & 61 & 32 & 15.66 & 7.11 & 14.99 & & 17.27 & 17.26 & .21 \\
\hline Tryptophan & 13.29 & 13.56 & 15.32 & 15.65 & 17.09 & 14.98 & 17.09 & 17.31 & 17.32 & 17.24 \\
\hline Tryptophan 1 & 13.52 & 13.76 & 15.50 & 15.83 & 17.18 & 15.16 & 17.18 & 17.29 & 17.31 & 17.26 \\
\hline Salicylic 100 ppm & 12.70 & 12.89 & 14.74 & 15.07 & 16.63 & 14.41 & 16.63 & 17.19 & 17.30 & 17.04 \\
\hline Salicylic 200 ppm & 12.63 & 12.85 & 14.74 & 15.07 & 16.61 & 14.38 & 16.61 & 17.15 & 17.34 & 17.03 \\
\hline Control & 12.98 & 13.17 & 15.14 & 15.31 & 16.95 & 14.71 & 16.95 & 17.30 & 16.93 & 17.06 \\
\hline Mean & 13.07 & 13.32 & 15.12 & 15.43 & 16.91 & & 16.91 & 17.25 & 17.24 & \\
\hline L.S.D at 0.05 & \multicolumn{6}{|c|}{$(A)=0.23,(B)=0.19,(A \times B)=0.51$} & \multicolumn{4}{|c|}{$(A)=0.23,(B)=0.15,(A \times B)=0.40$} \\
\hline
\end{tabular}

Table 14. Effect of arginine, tryptophan and salicylic acid treatments on TSS percentage of Le-Conte pear fruits during cold storage and shelf life in 2016 season

\begin{tabular}{|c|c|c|c|c|c|c|c|c|c|c|}
\hline \multirow{2}{*}{ Treatments (A) } & \multicolumn{6}{|c|}{ Weeks of storage at $0^{\circ} \mathrm{C}(\mathrm{B})$} & \multicolumn{4}{|c|}{ Days of shelf life at $22^{\circ} \mathrm{C}$ (B) } \\
\hline & Initial & 3 & 6 & 9 & 12 & Mean & Initial & 6 & 12 & Mean \\
\hline Arginine 100 ppm & 12.88 & 14.43 & 14.52 & 15.31 & 16.98 & 14.82 & 16.98 & 17.13 & 17.14 & 17.08 \\
\hline Arginine 200 ppm & 13.19 & 14.72 & 14.69 & 15.53 & 17.01 & 15.03 & 17.01 & 17.15 & 17.16 & 17.10 \\
\hline Tryptophan 50 ppm & 13.19 & 14.79 & 14.82 & 15.65 & 17.05 & 15.10 & 17.05 & 17.23 & 17.22 & 17.17 \\
\hline Tryptophan 100 ppm & 13.39 & 14.96 & 15.00 & 15.84 & 17.11 & 15.26 & 17.11 & 17.27 & 17.23 & 17.20 \\
\hline Salicylic 100 ppm & 12.60 & 14.22 & 14.47 & 15.26 & 16.87 & 14.68 & 16.87 & 17.07 & 17.17 & 17.04 \\
\hline Salicylic 200 ppm & 12.57 & 14.14 & 14.33 & 15.13 & 16.83 & 14.60 & 16.83 & 17.10 & 17.12 & 17.02 \\
\hline Control & 12.78 & 14.42 & 14.76 & 15.64 & 17.07 & 14.93 & 17.07 & 17.11 & 16.99 & 17.06 \\
\hline Mean & 12.94 & 14.53 & 14.66 & 15.48 & 16.99 & & 16.99 & 17.15 & 17.15 & \\
\hline L.S.D at 0.05 & \multicolumn{6}{|c|}{$(A)=0.24,(B)=0.20,(A \times B)=0.54$} & \multicolumn{4}{|c|}{$\begin{array}{c}(A)=0.12,(B)=0.08,(A \times B)= \\
0.22\end{array}$} \\
\hline
\end{tabular}

The obtained effects are in agreement with prior investigation for Ahmed et al (2017) on Washington navel orange, they found that foliar sprays by tryptophan at 25 and 50 ppm significantly increased fruit total soluble solids content. Refaat and Naguib (1998) reported that tryptophan led to increase in amino acid content in leaves, which directly effect on carbohydrate synthesis, and finally on sugars concentration in fruits.

On the other hand, salicylic acid at 100 and $200 \mathrm{ppm}$ delayed the increase in total soluble solids content in LeConte pear, in accordance with Reddy and Sharma (2016) who found that preharvest treatments to Amrapali mango fruits maintaining the post-harvest fruit quality and maintain soluble solid concentrations. Moreover, Ahmed et al (2013) found that salicylic acid preharvest treatments at 8 and $9 \mathrm{mM}$ were effective in maintaining
TSS content in 'Lane Late' and 'Valencia Late' oranges. Maintaining soluble solid content is related to salicylic acid treatment role in minimizing respiration and metabolism rates (Lu et al 2011).

\subsubsection{Total phenols (mg/ $100 \mathrm{~g}$ FWt)}

Phenolic compounds are secondary metabolites extensively found in fruits, generally represented as flavonoids and phenolic acids, which are considered as antioxidants in tissues (Haminiuk et al 2012). Effect of arginine, tryptophan and salicylic acid treatments on total phenols of Le-Conte pear fruits in 2015 and 2016 is presented in Tables 15 and 16. Fruit content of total phenols decreased continually with extended storage period.

Salicylic acid at 200 ppm significantly maintained total phenols of Le-Conte pear fruits, while 
control showed the lowest significant total phenols in both seasons. The conducted treatments showed higher values compared with control, by the end of storage period salicylic at $200 \mathrm{ppm}$ showed the highest significant total phenols (37.47 and $36.96 \mathrm{mg} / 100 \mathrm{~g} \mathrm{FWt}$ ), while control showed the lowest significant total phenols (30.83 and
$29.75 \mathrm{mg} / 100 \mathrm{~g} \mathrm{FWt}$ ). After 12 days of shelf life at $22^{\circ} \mathrm{C}$, salicylic acid treatment at $200 \mathrm{ppm}$ showed the highest significant total phenols (32.98 and $32.21 \mathrm{mg} / 100 \mathrm{~g} \mathrm{FWt}$ ), while control showed the lowest significant total phenols (27.13 and 26.01 $\mathrm{mg} / 100 \mathrm{~g} \mathrm{FWt}$ ) in the first and the second season respectively.

Table 15. Effect of arginine, tryptophan and salicylic acid treatments on total phenols (mg/ $100 \mathrm{~g} \mathrm{FWt)} \mathrm{of}$ Le-Conte pear fruits during cold storage and shelf life in 2015 season

\begin{tabular}{|c|c|c|c|c|c|c|c|c|c|c|}
\hline \multirow{2}{*}{ Treatments $(A)$} & \multicolumn{6}{|c|}{ Weeks of storage at $0^{\circ} \mathrm{C}(\mathrm{B})$} & \multicolumn{4}{|c|}{ Days of shelf life at $22^{\circ} \mathrm{C}(\mathrm{B})$} \\
\hline & Initial & 3 & 6 & 9 & 12 & Mean & Initial & 6 & 12 & Mean \\
\hline Arginine 100 ppm & 39.05 & 38.88 & 37.77 & 37.62 & 36.62 & 37.99 & 36.62 & 33.11 & 32.21 & 33.98 \\
\hline Arginine 200 ppm & 39.55 & 39.39 & 38.25 & 38.01 & 36.51 & 38.34 & 36.51 & 33.04 & 32.13 & 33.89 \\
\hline Tryptophan 50 ppm & 37.98 & 37.81 & 36.74 & 36.53 & 34.13 & 36.64 & 34.13 & 30.57 & 30.37 & 31.69 \\
\hline Tryptophan 100 ppm & 36.04 & 35.83 & 34.86 & 34.65 & 33.78 & 35.03 & 33.78 & 30.59 & 30.06 & 31.48 \\
\hline Salicylic 100 ppm & 39.71 & 39.54 & 38.41 & 38.21 & 37.40 & 38.65 & 37.40 & 33.85 & 32.88 & 34.71 \\
\hline Salicylic 200 ppm & 40.03 & 39.82 & 38.72 & 38.47 & 37.47 & 38.90 & 37.47 & 33.91 & 32.98 & 34.79 \\
\hline Control & 31.93 & 31.73 & 31.65 & 31.12 & 30.83 & 31.45 & 30.83 & 27.92 & 27.13 & 28.63 \\
\hline Mean & 37.76 & 37.57 & 36.63 & 36.37 & 35.25 & & 35.25 & 31.86 & 31.11 & \\
\hline L.S.D at 0.05 & \multicolumn{6}{|c|}{$(A)=0.39,(B)=0.33,(A \times B)=0.88$} & \multicolumn{4}{|c|}{$(A)=0.87,(B)=0.57,(A \times B)=1.52$} \\
\hline
\end{tabular}

Table 16. Effect of arginine, tryptophan and salicylic acid treatments on total phenols (mg/ 100g FWt) of Le-Conte pear fruits during cold storage and shelf life in 2016 season

\begin{tabular}{|c|c|c|c|c|c|c|c|c|c|c|}
\hline \multirow{2}{*}{ Treatments (A) } & \multicolumn{6}{|c|}{ Weeks of storage at $0^{\circ} \mathrm{C}(\mathrm{B})$} & \multicolumn{4}{|c|}{ Days of shelf life at $22^{\circ} \mathrm{C}$ (B) } \\
\hline & Initial & 3 & 6 & 9 & 12 & Mean & Initial & 6 & 12 & Mean \\
\hline Arginine $100 \mathrm{ppm}$ & 39.31 & 38.91 & 37.99 & 36.52 & 36.11 & 37.77 & 36.11 & 33.14 & 31.53 & 33.60 \\
\hline Arginine 200 ppm & 39.88 & 39.44 & 38.51 & 36.92 & 36.23 & 38.19 & 36.23 & 33.11 & 31.71 & 33.68 \\
\hline Tryptophan 50 ppm & 38.11 & 37.64 & 36.77 & 35.34 & 35.25 & 36.62 & 35.25 & 32.43 & 30.79 & 32.82 \\
\hline Tryptophan 100 ppm & 36.93 & 36.51 & 35.68 & 34.32 & 34.24 & 35.54 & 34.24 & 31.43 & 29.93 & 31.87 \\
\hline Salicylic 100 ppm & 41.02 & 40.60 & 39.60 & 38.13 & 36.36 & 39.14 & 36.36 & 33.35 & 31.79 & 33.83 \\
\hline Salicylic 200 ppm & 40.97 & 40.52 & 39.56 & 37.99 & 36.96 & 39.20 & 36.96 & 33.89 & 32.21 & 34.35 \\
\hline Control & 32.03 & 31.70 & 31.01 & 30.07 & 29.75 & 30.91 & 29.75 & 27.39 & 26.01 & 27.71 \\
\hline Mean & 38.32 & 37.90 & 37.02 & 35.61 & 34.99 & & 34.99 & 32.11 & 30.57 & \\
\hline L.S.D at 0.05 & \multicolumn{6}{|c|}{$(A)=0.56,(B)=0.47,(A \times B)=1.25$} & \multicolumn{4}{|c|}{$(A)=0.58,(B)=0.38,(A \times B)=1.00$} \\
\hline
\end{tabular}

Alves et al (2004) reported that the decrease in total phenolic levels is owing to breakdown of phenolic compounds by polyphenol oxidase during the storage period.

The function of salicylic acid is compatible with Sarikhani et al (2010) who found similar results in grape, whereas 2 and $4 \mathrm{mM}$ of salicylic acid significantly maintained phenols content in fruit. Also, Hadian-Deljou et al (2017) reported that salicylic acid at 2 and $4 \mathrm{mM}$ induced accumulation of phenolic compounds in 'Red Delicious' apples. Chen et al (2006) reported that maintaining phenolics might be due to phenylalanine ammonialyase ac- tivity, which is related to phenylpropanoid metabolism.

\subsubsection{Ascorbic acid (mg/ $100 \mathrm{~g} \mathrm{FWt)}$}

Ascorbic acid is an antioxidant that acts against reactive $\mathrm{O}_{2}$ species beside other substances such as $\alpha$-tocopherol that related to the ascorbateglutathione cycle, also ascorbic acid participate in the conversion of 1- aminocyclopropane-1carboxylic acid to ethylene (Smirnoff, 1996). In pear fruits, a correlation was found between ascorbic acid content and the susceptibility to browning, Veltman et al (1999) cited that pear cv. 

attributes of pear fruits cv. Le-Conte during cold storage and shelf life

Conference suffer browning core once ascorbic acid content decrease.

Tables 17 and 18 present the effect of arginine, tryptophan and salicylic acid treatments on ascorbic acid (mg/ $100 \mathrm{~g} \mathrm{FWt)} \mathrm{of} \mathrm{Le-Conte} \mathrm{pear}$ fruits in 2015 and 2016 seasons. Fruit content of ascorbic acid decreased gradually under all treatments conditions, salicylic acid at 200 ppm retained the highest significant ascorbic acid content during cold storage in both seasons, and shelf life in the first season, in addition to salicylic at 100 ppm that showed the highest ascorbic acid content during the shelf life in the second season. On the other hand, fruits from the untreated trees showed the lowest ascorbic acid content in pear fruit cv. Le-Conte.

In the first season, by the end of storage period salicylic at $200 \mathrm{ppm}$ showed the highest significant ascorbic acid (4.09 mg/ 100g FWt) while control showed the lowest significant ascorbic acid (3.36 $\mathrm{mg} / 100 \mathrm{~g} \mathrm{FWt}$ ), after 12 days of shelf life period salicylic at $100 \mathrm{ppm}$ showed the highest significant ascorbic acid $(2.05 \mathrm{mg} / 100 \mathrm{~g} \mathrm{FWt})$ while control showed the lowest significant ascorbic acid (1.48 $\mathrm{mg} / 100 \mathrm{~g}$ FWt).

In the second season, after 12 weeks cold storage period salicylic at $100 \mathrm{ppm}$ showed the highest significant ascorbic acid $(3.95 \mathrm{mg} / 100 \mathrm{~g}$ $\mathrm{FWt}$ ), while control showed the lowest significant ascorbic acid ( $3.36 \mathrm{mg} / 100 \mathrm{~g} \mathrm{FWt}$ ), also by the end of shelf life period salicylic acid treatment at 100 ppm showed the highest significant ascorbic acid (2.24 mg/ $100 \mathrm{~g} \mathrm{FWt)} \mathrm{while} \mathrm{control} \mathrm{showed} \mathrm{the}$ lowest significant ascorbic acid (1.93 mg/ 100g $\mathrm{FWt}$ ).

Ascorbic acid losses seem to have taken place due to the conversion of dehydroascorbic to diketogulonic acid due to oxidation (Ishaq et al 2009). The obtained data are in harmony with findings cited by Kazami et al (2011) who observed higher ascorbic acid content in apple fruits treated with salicylic acid, also, Reddy and Sharma (2016) in mango cv. Amrapali; whereas salicylic acid 200 ppm was effective in maintaining ascorbic acid.

Table 17. Effect of L-arginine, L-tryptophan and salicylic acid treatments on ascorbic acid content (mg/ $100 \mathrm{~g}$ FWt) of Le-Conte pear fruits during cold storage and shelf life in 2015 season

\begin{tabular}{|c|c|c|c|c|c|c|c|c|c|c|}
\hline \multirow{2}{*}{ Treatments $(\mathrm{A})$} & \multicolumn{6}{|c|}{ Weeks of storage at $0^{\circ} \mathrm{C}(\mathrm{B})$} & \multicolumn{4}{|c|}{ Days of shelf life at $22^{\circ} \mathrm{C}(\mathrm{B})$} \\
\hline & Initial & 3 & 6 & 9 & 12 & Mean & Initial & 6 & 12 & Mean \\
\hline Arginine $100 \mathrm{ppm}$ & 6.32 & 6.24 & 5.17 & 4.38 & 3.84 & 5.19 & 3.84 & 3.23 & 1.88 & 2.98 \\
\hline Arginine 200 ppm & 6.18 & 6.08 & 5.20 & 4.50 & 3.92 & 5.18 & 3.92 & 3.31 & 1.95 & 3.06 \\
\hline Tryptophan 50 ppm & 6.22 & 6.14 & 5.18 & 4.40 & 3.94 & 5.18 & 3.94 & 3.36 & 1.99 & 3.10 \\
\hline Tryptophan 100 & & & & & & & & & & \\
\hline ppm & 6.18 & 6.13 & 5.10 & 4.32 & 3.93 & 5.13 & 3.93 & 3.36 & 1.94 & 3.08 \\
\hline Salicylic 100 ppm & 6.32 & 6.20 & 5.16 & 4.44 & 3.87 & 5.20 & 3.87 & 3.30 & 2.05 & 3.08 \\
\hline Salicylic 200 ppm & 6.46 & 6.40 & 5.34 & 4.62 & 4.09 & 5.38 & 4.09 & 3.30 & 2.02 & 3.14 \\
\hline Control & 5.99 & 5.99 & 4.91 & 4.24 & 3.36 & 4.90 & 3.36 & 2.72 & 1.48 & 2.52 \\
\hline Mean & 6.24 & 6.17 & 5.15 & 4.41 & 3.85 & & 3.85 & 3.23 & 1.90 & \\
\hline L.S.D at 0.05 & \multicolumn{6}{|c|}{$(A)=0.09,(B)=0.07,(A \times B)=0.20$} & \multicolumn{4}{|c|}{$(A)=0.14,(B)=0.09,(A \times B)=0.24$} \\
\hline
\end{tabular}


Table 18. Effect of L-arginine, L-tryptophan and salicylic acid treatments on ascorbic acid content (mg/ $100 \mathrm{~g} \mathrm{FWt}$ ) of Le-Conte pear fruits during cold storage and simulated marketing life in 2016 season

\begin{tabular}{|c|c|c|c|c|c|c|c|c|c|c|}
\hline \multirow{2}{*}{ Treatments (A) } & \multicolumn{6}{|c|}{ Weeks of storage at $0^{\circ} \mathrm{C}(\mathrm{B})$} & \multicolumn{4}{|c|}{ Days of shelf life at $22^{\circ} \mathrm{C}$ (B) } \\
\hline & Initial & 3 & 6 & 9 & 12 & Mean & Initial & 6 & 12 & Mean \\
\hline Arginine 100 ppm & 6.75 & 6.23 & 5.62 & 5.15 & 3.79 & 5.51 & 3.79 & 2.79 & 2.09 & 2.89 \\
\hline Arginine 200 ppm & 6.62 & 6.01 & 5.59 & 4.95 & 3.82 & 5.40 & 3.82 & 2.81 & 2.18 & 2.94 \\
\hline Tryptophan 50 ppm & 6.73 & 6.14 & 5.65 & 5.11 & 3.75 & 5.48 & 3.75 & 2.60 & 2.06 & 2.80 \\
\hline Tryptophan 100 ppm & 6.77 & 6.15 & 5.50 & 5.05 & 3.86 & 5.46 & 3.86 & 2.69 & 2.11 & 2.89 \\
\hline Salicylic 100 ppm & 6.96 & 6.26 & 5.72 & 5.20 & 3.95 & 5.62 & 3.95 & 2.80 & 2.24 & 2.99 \\
\hline Salicylic 200 ppm & 7.03 & 6.28 & 5.78 & 5.24 & 3.92 & 5.65 & 3.92 & 2.80 & 2.21 & 2.98 \\
\hline Control & 6.27 & 5.60 & 5.09 & 4.56 & 3.36 & 4.97 & 3.36 & 2.40 & 1.93 & 2.56 \\
\hline Mean & 6.73 & 6.10 & 5.56 & 5.04 & 3.78 & & 3.78 & 2.70 & 2.12 & \\
\hline L.S.D at 0.05 & \multicolumn{6}{|c|}{$(A)=0.11,(B)=0.09,(A \times B)=0.25$} & \multicolumn{4}{|c|}{$(A)=0.14,(B)=0.09,(A \times B)=0.24$} \\
\hline
\end{tabular}

Salicylic acid is probably effective because of the stimulation of responsible genes for antioxidant substances production (Wang et al 2006) and induce antioxidant enzymes activity such as ascorbate peroxidase, superoxide dismutase, peroxidase and catalase (Mo et al 2008).

\subsubsection{Antioxidant capacity (mg/ 100g FWt)}

Data tabulated in Tables 19 and 20 illustrate the impact of arginine, tryptophan and salicylic acid treatments on antioxidant capacity of Le-Conte pear fruits in 2015 and 2016 seasons. Antioxidant capacity decreased steadily with prolongation storage period. In general, salicylic at 200 ppm showed higher antioxidant capacity values, in contrast, control showed the lowest significant antioxidant capacity in all cases.

By the end of cold storage period, salicylic at 200 ppm showed the highest significant antioxidant capacity (37.61 and $32.62 \mathrm{mg} / 100 \mathrm{~g}$ FWt) while control showed the lowest significant antioxidant capacity (32.11 and $29.66 \mathrm{mg} / 100 \mathrm{~g}$ FWt) in 2015 and 2016 seasons respectively.

In similar way, by the end of shelf life period salicylic at 200 ppm showed the highest significant antioxidant capacity (25.01 and $25.21 \mathrm{mg} / 100 \mathrm{~g}$ FWt) while control showed the lowest significant antioxidant capacity (20.90 and $21.85 \mathrm{mg} / 100 \mathrm{~g}$ FWt).

Table 19. Effect of L-arginine, L-tryptophan and salicylic acid preharvest treatments on antioxidant capacity (mg/ $100 \mathrm{~g} \mathrm{FWt)} \mathrm{of} \mathrm{Le-Conte} \mathrm{pear} \mathrm{fruits} \mathrm{during} \mathrm{cold} \mathrm{storage} \mathrm{and} \mathrm{shelf} \mathrm{life} \mathrm{in} 2015$ season

\begin{tabular}{|c|c|c|c|c|c|c|c|c|c|c|}
\hline \multirow{2}{*}{ Treatments (A) } & \multicolumn{6}{|c|}{ Weeks of storage at $0^{\circ} \mathrm{C}(\mathrm{B})$} & \multicolumn{4}{|c|}{ Days of shelf life at $22^{\circ} \mathrm{C}(\mathrm{B})$} \\
\hline & Initial & 3 & 6 & 9 & 12 & Mean & Initial & 6 & 12 & Mean \\
\hline Arginine 100 ppm & 43.74 & 43.61 & 42.26 & 40.40 & 37.21 & 41.44 & 37.21 & 30.10 & 24.42 & 30.57 \\
\hline Arginine 200 ppm & 44.30 & 44.18 & 43.08 & 40.93 & 36.96 & 41.89 & 36.96 & 29.37 & 24.21 & 30.18 \\
\hline Tryptophan 50 ppm & 44.47 & 44.39 & 42.98 & 41.07 & 37.10 & 42.00 & 37.10 & 30.07 & 24.27 & 30.48 \\
\hline Tryptophan 100 ppm & 44.84 & 44.77 & 43.25 & 41.39 & 36.63 & 42.18 & 36.63 & 29.34 & 23.95 & 29.97 \\
\hline Salicylic 100 ppm & 42.54 & 42.51 & 41.64 & 39.87 & 37.39 & 40.79 & 37.39 & 30.09 & 24.69 & 30.72 \\
\hline Salicylic 200 ppm & 40.36 & 40.30 & 39.59 & 38.94 & 37.61 & 39.36 & 37.61 & 30.02 & 25.01 & 30.88 \\
\hline Control & 35.76 & 35.21 & 34.70 & 33.47 & 32.11 & 34.25 & 32.11 & 26.18 & 20.90 & 26.40 \\
\hline Mean & 42.29 & 42.14 & 41.07 & 39.44 & 36.43 & & 36.43 & 29.31 & 23.92 & \\
\hline L.S.D at 0.05 & \multicolumn{6}{|c|}{$(A)=0.50,(B)=0.43,(A \times B)=1.13$} & \multicolumn{4}{|c|}{$(A)=0.62,(B)=0.40,(A \times B)=1.07$} \\
\hline
\end{tabular}



attributes of pear fruits cv. Le-Conte during cold storage and shelf life

Table 20. Effect of L-arginine, L-tryptophan and salicylic acid preharvest treatments on antioxidant capacity (mg/ 100g FWt) of Le-Conte pear fruits during cold storage and marketing life in 2016 season

\begin{tabular}{|c|c|c|c|c|c|c|c|c|c|c|}
\hline \multirow{2}{*}{ Treatments (A) } & \multicolumn{6}{|c|}{ Weeks of storage at $0^{\circ} \mathrm{C}(\mathrm{B})$} & \multicolumn{4}{|c|}{ Days of shelf life at $22^{\circ} \mathrm{C}$ (B) } \\
\hline & Initial & 3 & 6 & 9 & 12 & Mean & Initial & 6 & 12 & Mean \\
\hline Arginine $100 \mathrm{ppm}$ & 40.56 & 40.44 & 36.55 & 35.92 & 32.34 & 37.16 & 32.34 & 26.35 & 24.31 & 27.67 \\
\hline Arginine 200 ppm & 41.77 & 41.67 & 37.70 & 36.93 & 31.75 & 37.97 & 31.75 & 26.23 & 24.43 & 27.47 \\
\hline Tryptophan 50 ppm & 39.98 & 39.84 & 36.13 & 35.21 & 32.21 & 36.67 & 32.21 & 26.14 & 23.81 & 27.39 \\
\hline Tryptophan 100 ppm & 40.23 & 40.03 & 36.29 & 35.70 & 31.32 & 36.71 & 31.32 & 26.07 & 24.17 & 27.19 \\
\hline Salicylic 100 ppm & 42.12 & 41.80 & 37.96 & 37.36 & 32.56 & 38.36 & 32.56 & 26.88 & 24.85 & 28.10 \\
\hline Salicylic 200 ppm & 42.62 & 42.52 & 38.58 & 37.80 & 32.62 & 38.83 & 32.62 & 26.40 & 25.21 & 28.08 \\
\hline Control & 34.21 & 33.80 & 30.93 & 30.11 & 29.66 & 31.74 & 29.66 & 24.52 & 21.85 & 25.34 \\
\hline Mean & 40.21 & 40.02 & 36.31 & 35.58 & 31.78 & & 31.78 & 26.08 & 24.09 & \\
\hline L.S.D at 0.05 & \multicolumn{6}{|c|}{$(A)=0.33,(B)=0.28,(A \times B)=0.75$} & \multicolumn{4}{|c|}{$(A)=0.92,(B)=0.60,(A \times B)=1.60$} \\
\hline
\end{tabular}

Antioxidants are compounds that are capable of inactivating free radicals and their effects (Halliwell, 1996), this interaction led to antioxidant consumption with storage life prolongation.

Our results were in agreement with Knorzer et al (1999) who illustrated that salicylic acid application positively improve the efficiency of antioxidants in fruits, in addition to Reddy and Sharma (2016) in mango cv. Amrapali; whereas total antioxidant content was significantly maintained by salicylic acid application at 200 ppm. In this way, Hadian-Deljou et al (2017) found that salicylic acid at 2 and $4 \mathrm{mM}$ maintained antioxidants capacity in 'Red Delicious' apples.

Mo et al (2008) suggested that salicylic acid effect is related to the induction of antioxidant enzymes activity such as peroxidase, catalase, ascorbate peroxidase and superoxide dismutase enzymes.

\section{CONCLUSION}

In conclusion, all conducted preharvest treatments maintained higher significant fruit quality compared with untreated ones. Salicylic acid treatments at 100 and $200 \mathrm{ppm}$ exhibited the lowest weight loss percentages. L-tryptophan at 100 ppm showed the highest significant TSS values, while salicylic acid at 200 ppm showed the lowest significant TSS values during cold storage and shelf life circumstances. Salicylic at 200 ppm minimized the rate of decay incidence, showed the lowest significant respiration rates, also it was effective in alleviating browning. Salicylic at $200 \mathrm{ppm}$ significantly maintained pear fruits firmness, and showed higher fruits peel $h^{\circ}$ value, antioxidant capacity values, ascorbic acid content and total phenols concentration of pear fruits $\mathrm{cv}$. Le-Conte. The results of this study suggested that preharvest treatments of salicylic acid, arginine and tryptophan can be used as promising application not only for valued effects at harvest but also for positive impact on fruit quality during postharvest life, salicylic acid at $200 \mathrm{ppm}$ led to maintaining fruit quality during cold storage and shelf life.

\section{REFERENCES}

Abd-Elrazek E., Hassan H.S.A. and Gamal ElDin K.M. 2013. Effect of foliar application with salicylic acid, benzyladenine and gibberellic acid on flowering, yield and fruit quality of olive trees (Olea europaea L.). Middle-East J. of Scientific Res., 14(11), 1401-1406.

Abdel Aziz F.H., El-Sayed M.A. and Aly H.A. 2017. Response of Manfalouty Pomegranate Trees to Foliar Application of Salicylic Acid. Assiut J. Agric. Sci., 48(2), 59-74.

Ahmed F.K., Hamed N.A., Magdy A.I. and ELazazy A.M. 2017. Effect of Tryptophan and Some Nutrient Elements Foliar Application on Yield and Fruit Quality of Washington Navel Orange. J. of Hort. Sci. \& Ornamental Plants, 9(2), 86-97.

Ahmed S., Singh Z., Khan A. and lqbal Z. 2013. Pre-harvest application of salicylic acid maintain the rind textural properties and reduce fruit rot and chilling injury of sweet orange during cold storage. Pak. J. Agri. Sci., 50(4), 559-569. 
Alves R.E., Filgueiras H. and da Silva A. 2004. Postharvest ripening of 'Tommy Atkins' mangoes on two maturation stages treated with 1MCP. Acta Hort., 645, 627-632.

Amiot M.J., Tacchini M., Aubert S.Y. and Oleszek W. 1995. Influence of cultivar, maturity stage, and storage conditions on phenolic composition and enzymatic browning of pear fruits. J. Agric. Food Chem., 43, 1132-1137.

Amiot M.J., Tacchini M., Aubert S.Y. and Nicolas W. 1992. Phenolic composition and browning susceptibility of various apple cultivars at maturity. J. Food Sci., 57, 958-962.

A.O.A.C. 2012. Official methods of analysis $19^{\text {th }}$ ed. Guidelines for standard method performance requirements, Washington, D.C.; USA.

Babalar M., Pirzad F., Sarcheshmeh M., Talaei A. and Lessani H. 2018. Arginine treatment attenuates chilling injury of pomegranate fruit during cold storage by enhancing antioxidant system activity. Postharvest Biology and Technol., 137, 31-37.

Babalar M., Asghari M., Talaei A. and Khosroshahi A. 2007. Effect of pre- and postharvest salicylic acid treatment on ethylene production, fungal decay and overall quality of Selva strawberry fruit. Food Chem., 105, 449-453.

Bagni N. and Tassoni A. 2001. Biosynthesis, oxidation and conjugation of aliphatic polyamines in higher plants. Amino Acids, 20, 301-317.

Berta G., Altamura M.M., Fusconi A., Cerruti F., Capitani F. and Bagni N. 1997. The plant cell wall is altered by inhibition of polyamine biosynthesis. New Phytologist, 137, 569-577.

Biasi R., Bagni N. and Costa G. 1988. Endogenous polyamines in apple and their relationship to fruit set and fruit growth. Physiologia Plantarum, 73(2), 201-205.

Bonghi C., Ferrarese L., Ruperti B., Tonutti P. and Ramina A. 1998. Endo- $\beta-1,4$-glucanases are involved in peach fruit growth and ripening, and regulated by ethylene. Physiologia Plantarum, 102, 346-352.

Brand-Williams W., Cuvelier M.E. and Berset C. 1995. Use of free radical method to evaluate antioxidant activity. Food Sci. Technol., 28, 2530.

Brar J.S., Gupta N. and Gill M.S. 2014. Effect of pre and post-harvest treatments of salicylic acid on quality characteristics of peach (Prunus persica L.) fruits during storage. Progres Hort., 46(2), 217-221.

Champa W.A., Gill M.I., Mahajan B.V. and Arora N.K. 2015. Preharvest salicylic acid treatments to improve quality and postharvest life of table grapes (Vitis vinifera L.) cv. Flame Seedless. J. Food Sci. Technol., 52(6), 3607-3616.

Charles A., Leslie R. and Romani J. 1988. Inhibition of Ethylene Biosynthesis by Salicylic Acid. Plant Physiology, 88(3), 833-837.

Chen J.Y., Wen P.F., Kong W.F., Pan Q.H., Zhan J.C., Li J.M., Wan S.B. and Huang W.D. 2006. Effect of salicylic acid on phenylpropanoids and phenylalanine ammonialyase in harvested grape berries. Post-harvest Biol. Technol., 40, 6472.

Hadian-Deljou M., Esna-Ashari M. and Sarikhani H. 2017. Effect of pre- and postharvest salicylic acid treatments on quality and antioxidant properties of 'Red Delicious' apples during cold storage. Adv. Hort. Sci., 31(1), 3138.

Halliwell B. 1996. Antioxidants: the basics-what they are and how to evaluate them. In: Advances in Pharmacology (ed. Sies H.). pp. 320. San Diego, CA, USA: Academic Press.

Haminiuk C.W., Maciel G., Plata-Oviedo M. and Peralta R. 2012. Phenolic compounds in fruits an overview. Int. J. of Food Sci. Technol., 47, 2023-2044.

Hanfay A.A., Khalil M.K., Abd Ei-Rahman A.M. and Nadia A.M. 2012. Effect of zinc, tryptophan and indole acetic acid on growth, yield and chemical composition of Valencia orange trees. J. of Applied Sci. Res., 8, 901-914.

Imran H., Yuxing Z., Guoqiang D.U., Guoying W. and Jianghong Z. 2007. Effect of salicylic acid (SA) on delaying fruit senescence of Huang Kum pear. Front. Agric. China, 1(4), 456-459.

Ishaq S., Rathore H. and Awan S. 2009. The studies on the physico-chemical and organoleptic characteristics of apricot during storage. Pakistan J. Nutr., 8, 856-860.

Kazami M., Aran M. and Zamani S. 2011. Effect of salicylic acid treatments on quality characteristics of apple fruits during storage. Am J. Plant Physiol., 6, 113-119.

Khademi Z. and Ershadi A. 2013. Postharvest application of salicylic acid improves storability of peach (Prunus persicacv. Elberta) fruits. Int. J. of Agric. and Crop Sci., 5, 651-655.

Khedr E.H. 2016. Impact of 1-Methylcyclopropene and salicylic acid treatments on quality characteristics of "Keitt" mangos during storage and shelf life. J. of Hort. Sci., \& Ornamental Plants, 8(3), 192-199.

Kilany A.E. 1982. Effect of some growth regulators and horticultural practices on the growth, 
Influence of pre-harvest salicylic and some amino acids treatments on quality attributes of pear fruits cv. Le-Conte during cold storage and shelf life

productivity and keeping quality of Le-Conte pear. Ph.D. Thesis, Fac. Agric., Cairo Univ., Egypt, 162 p.

Knorzer O.C., Lederer B., Durner J. and Boger P. 1999. Antioxidative defense activation in soybean cells. Physiol. Plant., 107, 294-302.

Lu X., Sun D., Li Y., Shi W. and Sun G. 2011. Pre- and post-harvest salicylic acid treatments alleviate internal browning and maintain quality of winter pineapple fruit. Sci. Hort., 130, 97-101.

Luo Y. and Barbosa-Canovas G.V. 1997. Enzymatic browning and its inhibition in new apple cultivars slices using 4-hexylresorcinol in combination with ascorbic acid. Food Sci. and Technology Int., 3(3), 195-201.

Luo Z., Chen C. and Xie J. 2011. Effect of salicylic acid treatment on alleviating postharvest chilling injury of 'Qingnai' plum fruit. Postharvest Biol. Tec., 62,115-120.

Magwazaa L.S. and Opara U.L. 2015. Analytical methods for determination of sugars and sweetness of horticultural products-A review. Scientia Hort., 184, 179-192.

Mahajan B.V., Kumar D. and Dhillon W.S. 2013. Effect of different polymeric films on shelf life and quality of pear fruits under supermarket conditions. Indian J. Hort., 70, 309-312.

Martinez C., Pons E., Prats G. and Leon J. 2004. Salicylic acid regulates flowering time and links defense responses and reproductive development. Plant J., 37, 209-217.

Mazumdar B.C. and Majumder K. 2003. Methods on Physico-chemical Analysis of Fruits, Daya Publ. House, Delhi, India, pp. 93-139.

McCollum T., D' Aquino S. and McDonald R. 1993. Heat treatment inhibits mango chilling injury. HortSci., 28(3), 197-198.

McGuire R.G. 1992. Reporting of objective color measurements. HortSci., 27, 1254-1255.

Mitcham B., Cantwell M. and Kader A. 2003. Method for determining quality of fresh commodities. Perishables Handling Newsletter Issue No. 85

MO Y., Gong D., Liang G., Han R., Xie J. and Li W. 2008. Enhanced preservation effects of sugar apple fruits by salicylic acid treatment during post-harvest storage. J. Sci. Food Agric., 88, 2693-2699.

Mohseni F., Pakkish Z. and Panahi B. 2017. Arginine impact on yield and fruit qualitative characteristics of strawberry. Agric. Conspectus Scientificus, 82, 19-26.

Nambi V.E., Thangavel K., Shahir S. and Geetha V. 2015. Evaluation of colour behavior during ripening of Banganapalli mango using CIE-Lab and RGB colour coordinates. J. Appl. Hort., 17(3), 205-209.

Ortiz-Lopez H., Chang C. and Rbush D. 2000. Amino acid transporters in plants. Biochimica et Biophysica Acta (BBA) - Biomembranes, 1465(1-2), 275-280.

Page A.F., Minocha R. and Minocha S.C. 2012. Living with high putrescine: expression of ornithine and arginine biosynthetic pathway genes in high and low putrescine producing poplar cells. Amino Acids, 42, 295-308.

Pillitteri L.J., Bertling I., Khuong T., Chao C.T. and Lovatt C.J. 2010. Foliar-applied tryptophan increases total yield and fruit size of Navel orange and clementine mandarin. Acta Hort. (ISHS), 884, 729-736.

Reddy S.V.R. and Sharma R.R. 2016. Effect of pre-harvest application of salicylic acid on the postharvest fruit quality of the Amrapali mango (Mangifera indica). Indian J. of Agric. Sci., 86, 727-731.

Refaat A.M. and Naguib Y.N. 1998. Peppermint yields and oil quality as affected by application of some amino acids. Bull. Fac. Agric., Cairo Univ., 49(1), 89- 98.

Rhodes M.J. 1980. The maturation and ripening of fruits. In: Thimann K.V., Delman R.C., Roth and G.S. (eds), Senescence in Plants, pp. 157-205. CRC Press, Florida, USA.

Rugini E., Bongi G. and Mencuccini M. 1986. Effect of putrescine, l-arginine and cobalt on fruit set, ethylene content and apparent parthenocarpy in olive (Olea europaea L.). Acta Hortic., 179, 365-368.

Sarikhani H., Sasani-Homa R. and Bakshi D. 2010. Effect of salicylic acid and $\mathrm{SO}_{2}$ generator pad on storage life and phenolic contents of grape (Vitis vinifera L. Bidaneh Sefid and Bidaneh Ghermez) Acta Horticult., 877, 16231630.

Shafie M., Taghavi T.S. and Babalar M. 2010. Addition of salicylic acid to nutrient solution combined with postharvest treatments (hot water, salicylic acid, and calcium dipping) improved postharvest fruit quality of strawberry. Scientia Hort., 124(1), 40-45.

Sherif H.M., Abd El-Bary A. and Hamed M.M. 2013. Improving fruit quality of Le-Conte pear trees by spraying some chemical compounds. J. of Hort. Sci. \& Ornamental Plants, 5(3), 238246.

Smirnoff N. 1996. The function and metabolism of ascorbic acid in plants. Anal. Bot., 78, 661-669. 
Snedecor G.W. and Cochran W.G. 1989. Statistical methods, $8^{\text {th }} \mathrm{Ed}$. lowa State Univ. press, Ames, lowa, USA.

Srivastva M.K. and Dwivedi U.N. 2000. Delayed ripening of banana fruit by salicylic acid. Plant Sci., 158, 87-96.

Taiz L. and Zeiger E. 2010. Ethylene. In: Plant physiology, International edn, Sinauer Associates Inc., Publishers, Sunderland, Massachusetts USA, pp. 519-537.

Tareen M.J., Abbasi N.A. and Hafiz I.A. 2012. Postharvest application of salicylic acid enhanced antioxidant enzyme activity and maintained quality of peach cv. 'Flordaking' fruit during storage. Sci. Hort., 142, 221-228.

Tegedera M. and Rentsch D. 2010. Uptake and Partitioning of Amino Acids and Peptides Molecular Plant, 3(6), 997-1011.

Valero D., Diaz-Mula H.M., Zapata P.J., Castillo S., Guillen F., Martinez-Romero D. and Serrano M. 2011. Postharvest treatments with salicylic acid, acetylsalicylic acid or oxalic acid delayed ripening and enhanced bioactive compounds and antioxidant capacity in sweet cherry. Agric. Food Chem., 59, 5483-5489.

Veltman R.H., Kho R.M., van Schaik A.C., Sanders J. and Oosterhaven M.G. 2000. Ascorbic acid and tissue browning in pears (Pyrus communis L. cvs Rocha and Conference) under controlled atmosphere conditions. Postharvest Biology and Technol., 19, 129-137.

Veltman R.H., Sanders M.G., Persijn S.T., Peppelenbos H.W. and Oosterhaven J. 1999. Decreased ascorbic acid levels and brown core development in pears (Pyrus communis cv 'Conference'). Physiol. Plant, 107, 39-45.

Waliszewski K., Pardio V. and Ovando L. 2007. Control of polyphenol oxidase activity in banana slices during osmotic dehydration. Drying Technol., 25(2), 375-378.

Wang L., Chen S., Kong W., Li S. and Archbold D.D. 2006. Salicylic acid pretreatment alleviates chilling injury and affects the antioxidant system and heat shock proteins of peaches during cold storage. Post-harvest Biol. Technol., 41, 244251.

Woijick P., Skorupińska A. and Gubbuk H. 2016. Impacts of Pre- and Postbloom Sprays of Tryptophan on Calcium Distribution within 'Red Jonaprince' Apple Trees and on Fruit Quality. HortSci., 51, 1511-1516.

Yao H. and Tian S. 2005. Effects of pre and postharvest applications of salicylic acid or methyl jasmonate on inducing disease resistance of sweet cherry fruit storage. Postharvest Biol. Technol., 35, 253-262. 
المؤتمر الرابع عشر لبحوث التننمية الزراعية،

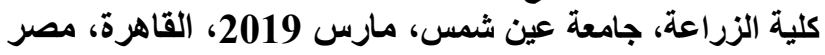

مجلد(27)، عدد(1)، عدد خاص مارس،

Website: http://strategy-plan.asu.edu.eg/AUJASCI/

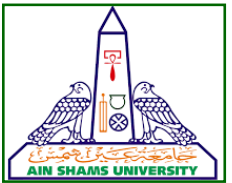

تأثير معاملات ما قبل الحصاد بحامض الساليسيليك ويعض الاحماض الامينية على جودة

ثمار الكمثرى الليكونت خلال التخزين المبرد والتعمر التسويقى

[58]

عماد الدين حمدى خضر

$$
\text { قسم بساتين الفاكهة- كلية الزراعة- جامعة القاهرة - جيزة - مصر حمر }
$$

Received 26 March, $2018 \quad$ Accepted 1 August, 2018

الكلية اثناء كل من التخزين المبرد لمدة اثنى عثر كمر

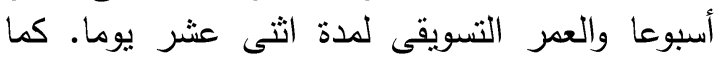
أدت المعاملة بحامض السيرفي اليسيليك بتركيز 100

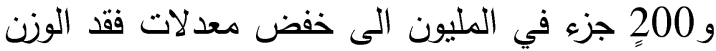

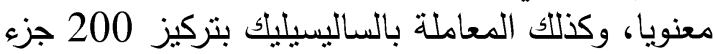

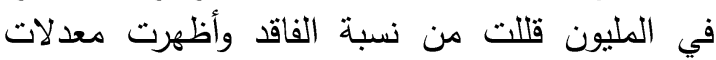
تنفس أقل، فضلا عن تقلبلها للتلون البنى. وأوضحت الدراسة أيضا ان المعاملة بحامض الساليسيليك بتركيز

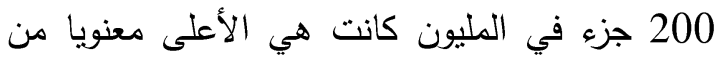

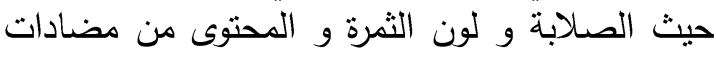

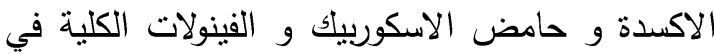
ثمار الكمثرى صنف الليكونت. لذا يستتنج ان الإن المعاملة

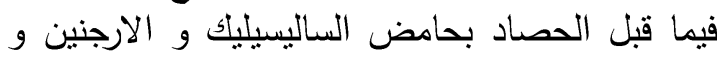

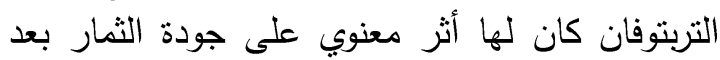

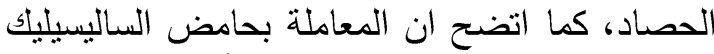

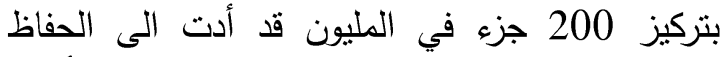

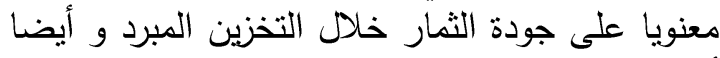
أثثاء فترة العمر التسويقى.

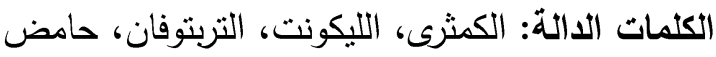

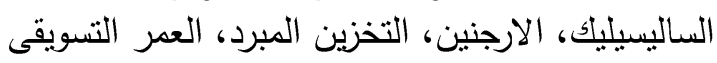

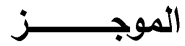

تم تتفيذ هذه الدراسة بهدف تقييم العلاقة بين

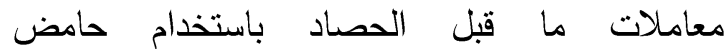

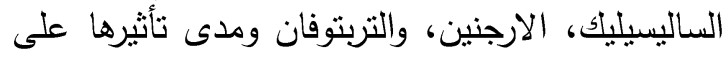

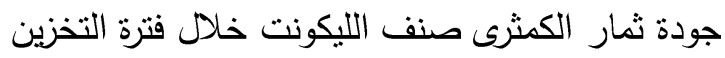

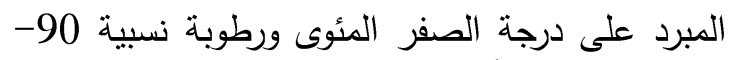
95 لمدة 12 أسبوع، متبوعة بالعمر التسويقى لمدة المدية

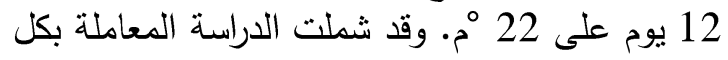

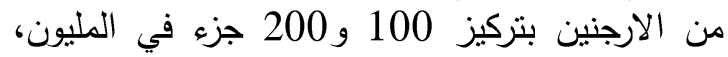

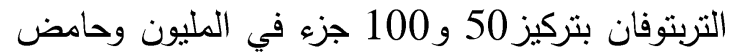
الساليسيليك بتركيز 100 و و200 جزيه في في المليون

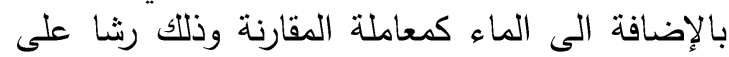
الأوراق للأشجار البالغة عند مرحلتى اكتمال التزهير والعقد المبدئى. وكانت كافة المعاملات لها تأثير فعال التئل

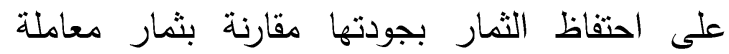

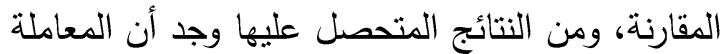

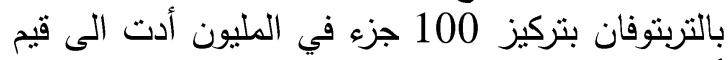

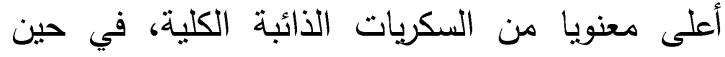

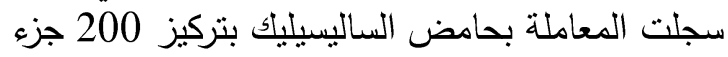
في المليون القيم الأقل معنويا من السكريات الذائبة 